An International Examination of the Economic Effectiveness of Banking Recapitalization

\author{
Suleiman Tahir \\ Planning Resource Ltd, Nigeria \\ E-mail: s.tahir@planningresourceltd.com \\ Emmanuel Adegbite \\ De Montfort University, UK \\ E-mail: emmanuel.adegbite@dmu.ac.uk \\ Yilmaz Guney \\ University of Hull, UK \\ E-mail: y.guney@hull.ac.uk
}

Citation: Tahir, S., Adegbite, E. and Guney, Y. "An international examination of the economic effectiveness of banking recapitalization”. International Business Review, 2017.

(C) 2018. This manuscript version is made available under the CC-BY-NC-ND 4.0 license http:// creativecommons.org/licenses/by-nc-nd/4.0/ 


\title{
An International Examination of the Economic Effectiveness of Banking Recapitalization
}

\begin{abstract}
While the literature on capital adequacy and bank recapitalization agrees on the importance of a minimum capital requirement, recurring financial crises across the world do little to suggest that capital adequacy is enough protection for banks, even when they fully comply. By examining the case of regulation compelled banking recapitalizations in a cross-country context (during the period 1990Q1 to 2016Q2), we scrutinize the effectiveness of banking recapitalization on the economies of recently recapitalized countries. We provide implications for international business research, practice and policy by highlighting the need for countries adopting the Basel capital adequacy framework to pay attention to the peculiarities of their economies, the supporting regulatory mechanisms and their comparative spare capacities.
\end{abstract}

JEL classification: G21, G28, E44

Keywords: Banking crisis; Financial risk, Bank regulation; Banking recapitalization; International business 


\section{Introduction}

The Basel regulatory capital frameworks focused on the need to create an adequate level of capital in the international banking system (Bank for International Settlements, 1988; 2001; 2011; 2013). Where there is a shortfall, banks are required or compelled by regulation to recapitalize. In agreement with such capital requirements, the bulk of the empirical literature in this space suggests that banking recapitalization improves the banking system's efficiency (VanHoose, 2007; Francis and Osborne, 2012). This literature argues that banking recapitalization increases the ability to expand the traditional lending role of banks in the economy and allows banks to have an increased ability to withstand adverse economic pressures, thereby providing more stability for international businesses and the international banking system (Berger and Bouwman, 2013 and Repullo and Suarez, 2013). However, even in the face of complete adherence to such capital requirements, the international banking system has consistently witnessed crises. This has led to questions about the effectiveness of capital adequacy requirements in ensuring bank vitality and depositors' protection. For instance, the failure to avert the 2007/2008 global financial crisis is the most recent criticism regarding the effectiveness of the Basel banking capital requirements in ensuring banking system stability. ${ }^{1}$

Previous empirical studies examining the effectiveness of banks' capital requirements have focused on immediate banking sector indices such as profitability, competition, loan creation, cost efficiency, amongst other micro indicators (see for example, Apergis, Fafaliou and Polemis, 2016; Francis and Osborne, 2012; Berger and Bouwman, 2013). These studies mostly relied on the

\footnotetext{
${ }^{1}$ A recent study by Markman and Venzin (2014) examined the resilience of the banking industry using the recent financial crisis as a stress test.
} 
assessments of banks' performance under inadequate and adequate capital, usually targeting periods, before, during and after recapitalization, to examine the effectiveness of banking recapitalization. However, there has been almost no attempt to understand the wider effectiveness of banking recapitalization on macroeconomic indicators such as industrial production, stock market indices, inflation rates, amongst others, especially in regulation compelled recapitalizations. Through the reactions of macroeconomic variables within five economies (Malaysia, Mexico, Nigeria, Spain and USA) chosen based on a defined selection criteria (highlighted in Section 4), this paper addresses this gap in literature and makes two important contributions to international business discourse.

First, this paper examines the effectiveness of banking recapitalization in the economies where banks were compelled to recapitalize by regulatory authorities in recent times. Specifically, we tested for the counter suggestion in Barrios and Blanco (2003) which argued that market forces rather than regulatory changes should determine banks' capital requirements. We tested the influence of regulatory compelled banking recapitalization on broad economic indicators such as industrial production (IP), exchange rate (ER), stock market index (SI), inflation (IR) and lending rate (LR). Our approach differs from the extant empirical studies which focused more on immediate banking sector variables (Apergis, Fafaliou and Polemis, 2016; Francis and Osborne, 2012; Berger and Bouwman, 2013). Even while the studies of Repullo and Suarez (2013) as well as Angelini, Neri and Panetta (2014) applied macroeconomic variables, these studies did not address the effectiveness of banking recapitalization on the economies of regulation compelled recapitalizing countries. While Repullo and Suarez (2013) concentrated on comparing Basel's capital regimes, Angelini, Neri and Panetta (2014) focused on the interaction between capital requirements and monetary policy. Similarly, Francis and Osborne (2012) only considered the 
exogenous effects of GDP (which is too general as an indicator of economic growth) on banking recapitalization. However, industrial production provides a more specific measure of banking recapitalization given its penchant for improving lending activities to the real sector of the economy (Dell'Ariccia, Detragiache and Rajan, 2008). A further dimension of our contribution here is our analysis of the effect of banking recapitalization on different sectors of the economy, a perspective which the extant empirical studies have not considered.

Our second contribution to international business literature comes from our examination of the periodic effect of banking recapitalization. Studying short-run dynamics as compared to long-run equilibrium provides a better understanding of the recapitalization effect. This allows us to delineate whether such effects are enduring or short-lived. Here, previous studies mostly focused on the broad time effect, with limited effort aimed at understanding whether banking recapitalization has short-run or long-run economic effects. Some of the existing studies examined crisis and crisis-free times (see e.g., Yildirim and Philippatos, 2007). As such, the exogenous application of macroeconomic variables under a broad timeframe as seen in Francis and Osborne (2012) is varied in the current study to account for direct periodic effects. Accounting for periodic effect will enable us to understand the wider economic implication of banking recapitalization on the productive sector and the dynamics of banking recapitalization in a cross-country context.

The remainder of this paper is organized as follows. Section 2 reviews relevant literature, including the relationship between banking recapitalization and macroeconomic indicators. The methodology and models are discussed in section 3 . We present our data in section 4 , where we also explain the choice of our investigated variables. In section 5, we present, analyze and discuss 
our results on the economic significance of banking recapitalization. In our concluding section, we present some implications of our study.

\section{Review of Literature on Banking Recapitalization: An International Appraisal}

The capital adequacy ratio stipulated in the Basel regulatory framework remains a widely acceptable measure for risk-based capital requirement internationally. This is vastly achieved through the stipulation of a minimum ${ }^{2}$ capital adequacy ratio which regulators enforce in ensuring that banks can absorb reasonable amounts of losses due to their operations. Where this falls below the minimum, banks will be required to recapitalize. However, different countries have had diverse experiences from banking recapitalization. For example, the recapitalization experiences of Malaysia (Sufian and Habibullah, 2013), Mexico (Yildirim and Philippatos, 2007; Maudos and Solís, 2011), USA (Repullo and Suarez, 2013) and Spain (Montes, 2014) resulted in a stronger banking and financial system. Both Maudos and Solís (2011) and Montes (2014), respectively, pointed how the Mexican and the Spanish economies were able to use banking recapitalization in managing adverse consequences of economic crises. Also, Sufian and Habibullah (2013) discussed how the Malaysian banking recapitalization was able to steer the economy out of the 1997 Asian financial crisis. In contrast, the Nigerian banking system became exposed to distress, with eight out of the country's twenty five banks having to be rescued by the central bank less than three years after the country's 2005 banking recapitalization program (Central Bank of Nigeria, 2011). ${ }^{3}$ The Nigerian example contradicts empirical findings, for example in Maudos and

\footnotetext{
${ }^{2}$ The Basel framework stipulates a common minimum holding of $8 \%$ risk-weighted assets for all international banks.

${ }^{3}$ We recognise that other factors relating to behavioural tendencies may contribute to some of these failures (for example, see VanHoose, 2007; Francis and Osborne, 2012).
} 
Solís (2011) and Montes (2014), which suggest that a country’s banking sector would be capable of avoiding financial distress by recapitalizing.

Different countries also have divergent targets with regards to recapitalization. On the one hand, apart from the US which has the tradition of continuous banking sector reforms, most of the aforementioned countries went into banking recapitalization to avert or react to a financial crisis. The Malaysian banking recapitalization, for example, was largely a reaction to the 1997 Asian financial crisis (Sufian and Habibullah, 2013), while the Spanish banking recapitalization was a direct response to the 2007-2008 global financial crisis (Montes, 2014). On the other hand, Barrios and Blanco (2003) suggest that market forces, rather than, regulatory changes determine banks' capital requirements. This implies that an economy has to be witnessing expansion activities for an increase in the banking sector capital base to be able to make much impact. Therefore, a growth in industrial production which is linked to improved bank lending as a result of recapitalization is expected to impact the economy positively.

Despite adherence to the Basel regulatory risk-based capital requirement by most countries, it is still not clear if such a measure is able to achieve the desired protection for banks in recapitalizing countries. Even as we see a compelling level of support for banking recapitalization (VanHoose, 2007; Francis and Osborne, 2012; Berger and Bouwman, 2013; and Repullo and Suarez, 2013), the effectiveness of such exercise on the economies of recapitalizing countries is not clear. However, banking recapitalization potentially increases banks' ability to expand their lending role as it gives access to more capital, which is expected to bring about economic expansion and stimulate more business activities. 
However, the focus of previous studies has been on the assessments of banks' performance during and after recapitalization. Here, studies have traditionally not examined the effectiveness of banking recapitalization on macroeconomic indicators. This gap in literature has begun to gain attention. For example, the effect of some macroeconomic indicators is documented in empirical studies such as Sufian and Habibullah (2013) as well as Maudos and Solís (2011) who respectively studied the Malaysian and Mexican recapitalization impacts. In Nigeria, Adegbite (2015) also highlighted the poor corporate governance practices, following banking recapitalization. Furthermore, Francis and Osborne (2012) as well as Berger and Bouwman (2013) indicated how poor behavioural conduct is capable of influencing the outcome of a banking recapitalization exercise. However, there is little attempt aimed at understanding the effectiveness of banking recapitalization on macroeconomic indicators such as industrial production, stock indices, inflation rates, amongst others.

Another important gap in literature relates to the stipulation of a common holding of $8 \%$ riskweighted assets for all international banks included in Basel I framework (Bank for International Settlements, 1988) as subsequently modified under Basel II and III frameworks. ${ }^{4}$ This provision has failed to recognize the divergent economic fundamentals and development stage of the different economies. By focussing on the wider economic effectiveness of banking recapitalization through the reactions of macroeconomic variables within five economies, this paper addresses these gaps in the literature. Our cross-country context narrative enriches international business

\footnotetext{
${ }^{4}$ It is important to note that the central banks in different countries as well as different economic unions apply the Basel capital adequacy requirement differently. For instance, the European Union countries, where Spain is a member, are required to have fully-loaded average core equity capital ratio to risk-weighted assets of $12 \%$ as against the $8 \%$ recommended in the Basel framework. Also, different countries ensure banking capital regulation is applied to their specific requirement. Thus, even as the European Union ensure a regular review of the Basel framework for consistency, the European Banking Authority implement the Basel framework to its member countries' situations. (Bank for International Settlements, 2014)
} 
discourse, given that the literature has concentrated on the effectiveness of banks' capital requirements, using micro-level banking sector indices and neglecting the wider macroeconomic effectiveness.

Our empirical approach also helps to contribute to the literature. Although the literature linking banking recapitalization and macroeconomic indicators is still evolving, a rich set of empirical attempts are in existence. ${ }^{5}$ The macroeconomic variables examined in these studies, which relates to banking capital, includes securities markets, monetary policy and productivity, GDP, stock returns and inflation amongst others. For example, both Angeloni and Faia (2013) and Angelini, Neri and Panetta (2014) focused on the need to understand the interaction between banking capital regulation and monetary policy. While Angelini, Neri and Panetta (2014) relied on a general equilibrium model to understand the interaction between capital requirements and monetary policy, Angeloni and Faia (2013) applied a macro model. These approaches did not have a broad focus and did less in terms of the specific challenge of measuring economic effectiveness of banking recapitalization, an important issue which this research is attempting to address. Thus, we separate the monetary policy variable applied in Angeloni and Faia (2013) and Angelini, Neri and Panetta (2014) by estimating the effect of banking recapitalization on inflation, which provides us with the much desired econometric solution to the problem. This is better assimilated than the dynamic solution of the general equilibrium models presented in the extant studies.

Furthermore, the relationship between banks' capital and stock return is equally examined in Demirgüç-Kunt, Feyen and Levine (2012) as well as in Demirguc-Kunt, Detragiache and

\footnotetext{
${ }^{5}$ See Demirgüç-Kunt, Feyen and Levine (2012); Francis and Osborne (2012); Angeloni and Faia (2013); DemirgucKunt, Detragiache and Merrouche (2013); Repullo and Suarez (2013); Angelini, Neri and Panetta (2014) for recent examples.
} 
Merrouche (2013). Using different types of capital ratios, Demirguc-Kunt, Detragiache and Merrouche (2013) have found that stronger capital in banks lead to better stock market performance during economic crisis. Similarly, Demirgüç-Kunt, Feyen and Levine (2012) found countries in the process of economic development to have both their banks and securities markets increase simultaneously. Both studies concentrated on the examination of banks' stock returns while ignoring the market index. As such, we consider the wider economic implication of banking recapitalization given the overall stock market index. This approach enables us to understand the larger effect of recapitalization on the economies of recapitalizing countries. Lastly, the effect of banking recapitalization on productivity has received limited attention. Even as Francis and Osborne (2012) examined the effects of banking recapitalization on the U.K. GDP, the empirical process only considered the exogenous effect of the GDP. ${ }^{6}$ In addressing these gaps, we test for the direct effect of banking recapitalization on the industrial production and inflation of the five recapitalizing countries to understand the wider economic implication of banking recapitalization on the productive sector.

The effectiveness of banking recapitalization in countries across five continents, including Malaysia, Mexico, Nigeria, Spain and USA were examined. We chose these economies using a defined selection criterion which includes recent and similar banking recapitalization experiences, and major economic influences in their respective continents. For instance, Nigeria is Africa's largest economy with a recent case of banking recapitalization (shortly before the 2007/2008 economic crisis), which remains largely unexamined. Nigeria also helps to serve as a contrasting basis for our data sample. The US data are applied mainly due to the recent global economic crisis

\footnotetext{
${ }^{6}$ While Demirgüç-Kunt, Feyen and Levine (2012) as well as Demirguc-Kunt, Detragiache and Merrouche (2013) included GDP and inflation in their samples, a prominent consideration was not given to these variables.
} 
which largely originated from the country's subprime mortgage lending. Also, the US dollar is the currency of international settlement with wide influence on the economies of most countries of the world. Mexico and Spain are similarly considered due to their common adoption of banking recapitalization as a response to the 2007-2008 economic crisis and Malaysia in response to the 1997 Asian financial crisis (Maudos and Solís, 2011; Sufian and Habibullah, 2013; Montes, 2014). In combination, we examine these economies to provide a global spread to our sample, in addition to providing a comparative analysis. There were both similarity and variance across the experiences of the investigated countries, prominently reflecting a divide between developed and developing economies. This presents an intriguing international business research, practice and policy enquiry, which we examine in this paper. We do this by asking how effective the capital adequacy ratio advocated by the Basel regulatory capital frameworks is in ensuring stability in the banking system of investigated countries.

\section{Methodology and Models}

This paper examines the economic implications of banking recapitalization using a variant of the Generalised Forecast Error Variance Decomposition (GFEVD) (Pesaran and Shin, 1998). GFEVD explores the interrelationships between economic variables by explicitly accounting for contemporaneous correlations between them. This expresses the percentage of the forecast error variance of variable $i$ that can be attributed to variable $j$. This is in addition to being invariant with respect to the ordering of the variables in the model, a problem which the earlier forecast error variance decomposition (Sims, 1980) has been unable to overcome. The model GFEVD also helps to test the associated Impulse Response Functions (IRF) which examines the effect of shock introduction due to banking recapitalization. In addition to doing these, we seek to further increase the robustness of our empirical process by adopting the Autoregressive Distributed Lag (ARDL) 
model (Pesaran, Shin and Smith, 2001) as well as the causality procedure of Toda-Yamamoto (Toda and Yamamoto, 1995).

In determining both IRF and their associated GFEVDs, the Vector Error Correction (VEC) also has to be estimated. The VEC will seek to estimate a system of equations in a variant of the vector autoregressive model (VAR). This is because the macroeconomic variables, such as industrial production, inflation and exchange rates, which will help us to understand the impact of banking recapitalization, are usually found to be non-stationary. In determining the VEC, an understanding of the long-run relationships between associated variables is necessary. In the context of establishing the economic effectiveness of banking recapitalization, the Johansen model (Johansen, 1988) for cointegration analysis offers a system approach in which more than one co-integrating vector might be identified. Furthermore, the greater efficiency offered by the approach makes it appropriate for our paper as opposed to other traditional approaches such as Engle and Granger (1987) and Gonzalo and Granger (1995). The process is first carried out by identifying cointegrating relationships, the residuals from which are then entered into a second VEC model. A simplified two-variable VEC model takes the form below:

$$
\begin{gathered}
y_{2, t}=\beta y_{1, t} \\
\Delta y_{1, t}=\alpha_{1}\left(y_{2, t-1}-\beta y_{1, t-1}\right)+\gamma_{1} \Delta y_{2, t-1}+\mathrm{e}_{1, t} \\
\Delta y_{2, t}=\alpha_{2}\left(y_{2, t-1}-\beta y_{1}, t-1\right)+\gamma_{2} \Delta y_{1, t-1}+\mathrm{e}_{2, t}
\end{gathered}
$$

where Eq. (1) is a co-integrating relationship and Eq. (2) is the VEC in which each of the dependent variables, $\boldsymbol{y}_{\boldsymbol{1}}$ and $\boldsymbol{y}_{2}$, adjusts to the deviation from the long-run equilibrium defined in Eq. (1), as well as the preceding changes in the values of the other variable. However, moving to more than two variables increases the numbers of potential in (1) and (2). 
VEC systemic analysis will usually consider a case of more than two variables, which may include exogenous variables. In examining the effect of banking recapitalization on the economy, some variables could be considered as exogenous to the model. The extant literature (for example, Francis and Osborne, 2012; Berger and Bouwman, 2013) has indicated how variables such as pricing, economic crisis, behavioural issues, amongst others, are capable of influencing the outcome of a banking recapitalization exercise. Thus, given that the specific focus of the current paper is on economic effectiveness, the global financial crisis in 2007/2008, and the earlier Asian financial crisis of 1997-1999 are considered as exogenous factors capable of influencing the outcome of banking recapitalization. This exogenous effect is captured in the form of a dummy variable (DUM) relating to the global financial crises. The dummy effect takes the value of "1" during the crisis years and " 0 " for the non-crisis years for both crises mentioned previously. Consequently, the VEC will be modelled with an endogenous effect coming from the macroeconomic variables, while the exogenous effect will come from the dummy variable (DUM). ${ }^{7}$

In examining economic significance, the GFEVD can be constructed by generalising $y_{1, t}$ and $y_{2, t}$ in Eq. (1) as a system of $K$ variables. $Y_{t}$, is written as an infinite moving average process:

$$
Y_{t}=\sum_{i=0}^{\infty} C_{i} \varepsilon_{t-i}
$$

the $\boldsymbol{n}$ step-ahead GFEVD is defined as

\footnotetext{
${ }^{7}$ Capturing the effects of financial crises will help to disentangle the effect of recapitalization from the effect of the financial/economic crises in our model. Therefore, in our dummy variable construction, we use the value "1" to measure crises years and " 0 "to measures crises-free years.
} 


$$
\theta_{i j}(n)=\frac{\sigma_{i j}^{-1} \sum_{k=0}^{n}\left(e_{i}^{\prime} C_{k} \Sigma e_{j}\right)^{2}}{\sum_{k=0}^{n} e_{i}^{\prime} C_{k} \Sigma C_{k}^{\prime} e_{j}} \text { for } i, j=1, \ldots, K
$$

where $\sigma_{\mathrm{ij}}$ denotes the $j^{\text {th }}$ diagonal entry of the residual covariance matrix, $\Sigma$; $\mathrm{e}_{\mathrm{j}}$ is the variable which assumes forecast error attributed to $j$; and $\mathrm{e}_{\mathrm{i}}$ is a $K \times 1$ vector with 1 in the $j^{\text {th }}$ row and 0 's elsewhere. In order to ease interpretation, Eq. (4) is therefore normalized as shown above.

$$
\sum_{j=1}^{K} \theta_{i j}(n)=1
$$

In Eq. (5), $\theta_{\mathrm{ij}}(\mathrm{n})$ is a measure of the cumulative system effects on variable $i$, which is a downstream of an initial shock in variable $j$. Thus, since the focus of our paper is the economic implication of banking recapitalization, GFEVDs will be presented as the aggregate of industrial production, the stock market indices, the interest rate and the inflation rate. In addition to this, the associated IRF will also be presented. The IRF will examine the effect of introducing a shock to the $j^{\text {th }}$ equation, at time $\mathrm{t}$ (banking recapitalization), on the values of the $i^{\text {th }}$ variable, at time $t+n$ (economic indicators).

We further adopt the Autoregressive Distributed Lag (ARDL) model proposed by Pesaran, Shin and Smith (2001). There are five econometric advantages of the ARDL model for our study, which include: i) it can be applied irrespective of whether the variables are integrated of order 1 (i.e., $I(0))$ or $I(1)$ or fractionally integrated; ii) it can be applied regardless of the exogeneity and stationarity assumptions of variables; iii) it can be applied without prior knowledge of the ranks of the variables for cointegration; iv) it does not suffer from small sample bias; and v) it can provide a joint estimation of both long-run and short-run parameters. We employ the following 
single equation reduced form of the ARDL method, adopting an unrestricted error correction model (UECM):

$$
\begin{aligned}
& \Delta Y_{t}=\alpha_{0}+\sum_{i=1}^{n 1} \beta_{1 i} \Delta Y_{t-i}+\sum_{i=0}^{n 2} \beta_{2 i} \Delta X 1_{t-i}+\sum_{i=0}^{n 3} \beta_{3 i} \Delta X 2_{t-i}+\sum_{i=0}^{n 4} \beta_{4 i} \Delta X 3_{t-i}+ \\
& \sum_{i=0}^{n 5} \beta_{5 i} \Delta X 4_{t-i}+\sum_{i=0}^{n 6} \beta_{6 i} \Delta X 5_{t-i} \lambda_{1} Y_{t-1}+\lambda_{2} X 1_{t-1}+\lambda_{3} X 2_{t-1}+\lambda_{4} X 3_{t-1}+\lambda_{5} X 4_{t-1}+ \\
& \lambda_{6} X 5_{t-1}+\varepsilon_{t}
\end{aligned}
$$

where $Y$ is one of the variables from the set of six factors as discussed previously (i.e., RECAP, SI, LR, IP, ER and IR) and $X 1$ to $X 5$ are the remaining variables of the same set. $\beta$ s and $\lambda$ s represent the short-run effects as a persistence measure of the variables and long-run parameters, respectively. The notation $\varepsilon$ is the white noise error term. The model also includes our exogenous binary dummy variable. The optimal lag length is determined by the Akaike information and Schwarz criteria, although we also paid attention to the absence of serial correlation in the residuals.

The 'bounds' test linked to the ARDL setting investigates the presence of long-term associations among the variables before separately quantifying the short-term and long-term effects. In this test, the $F$-statistics is provided with upper critical (assuming regressors are $I(1)$ ) and lower critical (assuming regressors are $I(0))$ asymptotic bounds which helps to determine the presence of a longrun relationship based on the null hypothesis that the coefficients on the level variables are jointly zero. ${ }^{9}$ The $t$-test helps to examine the individual significance of coefficient estimates on the lagged level dependent variable. Our ARDL procedure also produces an error correction term (ECT) which can help clarify if there is a long-run causality as well as help to measure the speed of convergence to a long-run equilibrium.

\footnotetext{
${ }^{8}$ For brevity, the other equations in which X1, X2, X3, X4 and X5 are the dependent variables are not shown.

${ }^{9}$ In other terms, $H o: \lambda_{1}=\lambda_{2}=\lambda_{3}=\lambda_{4}=\lambda_{5}=\lambda_{6}=0$ against $H a$ : at least one $\lambda$ is non-zero. On the one hand, if our test statistic is greater than the upper critical value, the presence of a long-term link is confirmed. On the other hand, if it is lower, the null of 'no cointegration' cannot be rejected; and any figure in between suggests inconclusive evidence.
} 
In order to bring additional rigor to our results, we employ the causality procedure of TodaYamamoto (Toda and Yamamoto, 1995). We chose this approach given that the standard Granger causality method is not consistent, as it employs Wald test only in a long-run equilibrium situation. Toda and Yamamoto (1995) suggested using a modified Wald (M-Wald) test statistics, which is not conditional upon the cointegration and stationarity properties of series but has the standard asymptotic distribution. In addition, unlike Granger test that is based on first-differencing, this procedure employs variables in levels and hence mitigates the risk of wrongly identifying the order of variables' integration $(I)$. This approach is illustrated as follows:

$Y_{t}=\alpha_{0}+\sum_{i=1}^{k} \beta_{1 i} Y_{t-i}+\sum_{j=k+1}^{d m a x} \beta_{2 i} Y_{t-j}+\sum_{i=1}^{k} \lambda_{1 i} X_{t-i}+\sum_{j=k+1}^{d \max } \lambda_{2 i} X_{t-j}+\varepsilon_{t}$

where $Y$ or $X$ is one of the aforementioned variables (i.e., RECAP, SI, LR, IP, ER and IR); $\alpha_{0}, \beta$ s and $\lambda \mathrm{s}$ are estimable parameters; and $\varepsilon$ is the error term. The model also includes our exogenous binary dummy variable. We use a standard unrestricted VAR (k) setting and the optimal lag length is determined by the Akaike information and Schwarz criteria. The notation dmax is the maximal order of integration that this procedure requires to artificially extend the VAR system. The new augmented system will therefore have the order " $k+d m a x "$. The earliest lag is used for all variables to treat them as exogenous whereas the latest lags are assigned to the same variables to treat them as endogenous. To justify the presence of causality from $X$ to $Y$ in Eq. (7), $\lambda$ s should be statistically different from zero. Thus, the relevant null hypothesis is that 'there is no causality from variable $X$ to variable $Y$ '.

\footnotetext{
${ }^{10}$ Again, for brevity, we did not show other equations in which the dependent variable is one of the aforementioned six factors.
} 


\section{Data and Sample Construction}

Given this paper's focus on the effectiveness of banking recapitalization on the economies of regulation compelled recapitalizing countries ${ }^{11}$, we apply the following macroeconomic variables; stock indices, industrial production, lending rate, exchange rate and inflation rate, which were obtained from Thomson Reuters Datastream. In addition to these variables, we constructed a recapitalization variable (RECAP) $)^{12}$ applied to measure the direct effect of recapitalization on the aforementioned countries' economies. We also applied a dummy variable (DUM) to capture the exogenous effect relating to the 2007/2008 global financial crisis and the Asian financial crisis of 1997-1999. Adopting this approach helped to separate the effect of recapitalization from the effect of the financial/economic crises. Given that the variables are economic indicators, the data were obtained in a quarterly format. The sample period was from 1990Q1 to 2016Q2 which helped to capture each country's specific experience. The period allowed 5 to 10 years before a major

\footnotetext{
${ }^{11}$ As mentioned earlier, the countries (Malaysia, Mexico, Nigeria, Spain and USA) were selected based on five unifying criteria which are: (1) countries with a case of regulation compelled banking recapitalization; (2) experience of this occuring in recent times; (3) availability of data which cover a significant period before and after recapitalization; (4) continental representativeness of the countries' macroeconomic indicators, and (5) inclusion of developing and developed economies. Of course, several factors are usually responsible for banking sector recapitalization in a given economy (see e.g., Yildirim and Philippatos, 2007). However, we choose to concentrate on the listed five given the focus of our paper, which is on regulatory compelled recapitalization.

12 We constructed the Recapitalization variable using the motivations (reasons) and timings of banking recapitalizations in each country. For Mexico, Spain and the U.S., recapitalizations were largely as a response the 2008 global economic crisis, so we constructed RECAP variables for these countries to take effect from 2008Q1 up until 2009Q4 (for guidance on precise recapitalization timings in these economies see Maudos and Solís, 2011; Montes, 2014; Bank of Spain, 2015). Malaysia recapitalized as a response to the 1997 Asian financial crisis, as a result, we constructed a RECAP variable to take effect from 1997Q3 up until 1999Q2 (for timing guidance, see Central Bank of Malaysia, 2002). Nigerian recapitalization was carried out in fulfilment of the Basel basic capital adequacy requirement and took effect from 2006Q1. We, therefore, constructed the RECAP variable to last up to 2007Q4 (see Central Bank of Nigeria, 2004). Thus, we assumed 8 quarters ( 2 years) as periods for the recapitalization effect on the recapitalizing countries' economies, basing our construction of the RECAP around the time which the countries experienced regulatory compelled recapitalization. Therefore, we assume recapitalization effect will normally commence on the year after start of the policy and last for 2 years. Hence, quarters of recapitalization take the effect of " 1 " and quarters of no recapitalization take the effect of " 0 ". Timing of our recapitalization variables selection/construction was also guided by the outcomes of the structural break timing of our sample (see Pesaran and Timmermann, 2007 for more insights). See Table 2D for the outcomes of sample break test, which further indicates that the majority of the break timing coincided with the recapitalization timing.
} 
recapitalization event and 5 to 10 years after recapitalization. The start and the end dates were predetermined to coincide with periods of no banking recapitalizations and periods of banking recapitalizations in each selected economy.

In addition, we selected countries bearing in mind continental spread/representation and based on the classification provided in the World Bank's database under World Development Indicators (WDI) table (World Bank, 2015). The selected countries fulfilled the above set criteria and between them accounted for about $30 \%$ of global GDP in 2014. Our sample also provided diversity, continental experiences and global coverage, paying attention to geographic influence within continental economy, trade and finance. Although, the selected countries shared the same experience of banking recapitalization, they have also developed divergent outcomes from the exercises, which constitute a subject of inquiry for this paper.

With respect to our selected variables, the number was determined on the basis of the rich set of dynamics within the adopted VAR model, which allowed a simultaneous analysis of multiple variables. Industrial production was included instead of GDP due to our aim of understanding the effectiveness of banking recapitalization on the real sector of the economy. GDP measures broad activities in the economy, whereas industrial production focuses on the industrial activities. Owing to the usual target of banking reforms in improving lending activities to the real sector of the economy, industrial production is a better measure for the objective of this study. Also, applying GDP will be misleading for some of the countries in the data sample. Nigeria, for instance, gets more than $90 \%$ of its foreign exchange earnings from oil (Central Bank of Nigeria, 2015). This situation implies that oil makes a significant contribution to the country's GDP. 
Furthermore, lending rates have important implications for the banking sector and hence the economy. Lending rates largely determine borrowing choices for all economic agents (GonzalezAguado and Suarez, 2015); the higher the rates, the lower the economic activities in the given economy. Also, stock market index is included to capture the wider economic effectiveness of banking recapitalization, which usually comes with increased stock market activities. This is either caused through banking stock recapitalization or mergers/acquisitions of the existing banks. Inflation rates are included to capture growth due to real growth or due to inflationary trend. Exchange rates are adopted to test the effectiveness of banking recapitalization on local currency exchange in relation to foreign currencies. Central banks traditionally maintain a strong foreign reserve account to defend their local currency from depreciation. However, good international perception on the strength of the local banking system can help to maintain a stable foreign exchange. Additionally, the effect of the recent global economic crisis, which originated from the US subprime mortgage lending, and the influence of the US dollar on the economies of recapitalizing countries of the world could be captured by including exchange rates in the analysis. The exchange rates of each analysed country's currency in relation to the US dollars are the adopted benchmark.

\section{Data Analysis, Results and Discussions}

Countries names are abbreviated as: MA, ME, N, S and US to represent Malaysia, Mexico, Nigeria, Spain and USA, respectively. Variables in each country are then named after these abbreviations. As such, stock market indices, lending rates, industrial production, exchange rates and inflation rates are respectively represented with the following acronyms: SI, LR, IP, ER and IR. Thus, our data - MASI, MALR, MAIP, MAER and MAIR; MESI, MELR, MEIP, MEER and MEIR; NSI, NLR, NIP, NER and NIR; SSI, SLR, SIP, SER and SIR; USSI, USLR, USIP, USER and USIR, 
represented the respective countries under consideration, while RECAP represents recapitalization variable in the case of each country. Most variables were applied in their log and log difference forms and these are indicated in the text where appropriate. The analyses of variables relating to the different models were however applied in their most suitable form. For instance, cointegration procedures were applied in log form, whereas the VEC procedures were applied in log difference form, due to the different needs in analysing each situation.

In line with the tradition of time series data application, relevant diagnostics tests were carried out to gauge the acceptability of the estimates. These procedures, in addition to other tests, such as the unit root and Granger causality tests, were carried out in accordance with standard practice. ${ }^{13}$ Table 1 presents the descriptive statistics for the selected variables. Most data series for the sample period were relatively stable for the examined countries.

\section{[INSERT TABLE 1 HERE]}

Tables 2A, 2B and 2C respectively presents augmented Dickey-Fuller (ADF), Phillip-Perron (PP) and Kwiatkowski-Phillips-Schmidt-Shin (KPSS) stationarity tests. Table 2D is the outcome of the structural break test. The ADF test results in Table 2A was carried out to check the datasets for stationarity, and avoid the danger of spurious regression. On the left panel of the Table, the tests reveal that Malaysian, Mexican, Nigerian and Spanish inflation rates are stationary in level terms. All other variables in the series were found to be non-stationary in level terms. This data series behavior is expected and usually common to times series data analysis. The right panel of the table

\footnotetext{
${ }^{13}$ For relevance and brevity, only some of the preliminary and diagnostics process outcomes are reported here.
} 
reveals the ADF test results at first difference. Here, the outcomes of all tests become stationary at the $1 \%$ level of significance.

\section{[INSERT TABLES 2A and 2B HERE]}

Table 2B presents the alternative Phillips-Perron (PP) stationarity test carried out based on NeweyWest (N-W) bandwidth criterion. Comparing the results of both ADF and P-P tests from Tables 2A and $2 \mathrm{~B}$ reveals no significant difference between the two tests outcomes. Only Malaysian and Nigerian inflation rates are stationary in level terms. To minimise the potential bias towards $I(1)$, we further implemented the Kwiatkowski-Phillips-Schmidt-Shin (KPSS) test to check for conformity. Table $2 \mathrm{C}$ is the KPSS test outcomes which suggest that the results have no significant difference from the earlier ADF tests. We also implemented the breakpoint test of Perron and Vogelsang (1992) in testing the possible existence of structural break(s). The outcome of the tests is presented in Table 2D with structural break period indicated in the case of each variable. As shown in the case of each series' period break, there appears to be no significant issues with the break timing in all data series. In addition, the series' break timing provided useful information for constructing the applied dummy variables.

\section{[INSERT TABLES 2C and 2D HERE]}

The Johansen cointegration test (Johansen, 1988) was implemented to understand the long-run relationships between the variables. In each country's case, the model estimation is based on the aforementioned variables, in addition to the dummy applied as an exogenous variable. Table 3 presents the cointegration test results, showing a common pattern of occurrences across countries. It is also important to note that both the trace and the maximum eigenvalue tests returned at least four cointegrating equation in the case of each country. These outcomes, therefore, strongly reject the null hypothesis that there is no cointegration. 


\section{[INSERT TABLE 3 HERE]}

The above analysis provides an insight into the practicality and relevance of the VEC specification, as we have shown the presence of cointegrating vectors and their associated models in examining banks' recapitalization. This further helps to understand the short-run dynamics and long-run economic equilibrium of banking recapitalization. Here, a system of equations in VEC form is estimated to correct non-stationary errors in the associating macroeconomic variables.

Table 4 presents the results of the VEC model estimates, assuming the presence of $(V A R(1))$ process. The results are interpreted based on their statistical significance and as such are carried out with a lot of caution, given the rich set of dynamics in a typical VEC model. Recap variables lag period in the case of all countries were not significant in explaining all other variables. Only the lag periods of Spain and U.S. inflation rates were negatively significant in explaining their respective Recap variables. This point may suggest the two countries' economic activities have been negatively impacted by the economic crises periods considered in our data sample. The dummy variable $(D U M)$ is applied to capture the exogenous effect of the global financial crisis 2007/2008, and the earlier Asian financial crisis of 1997 on the VEC model. There is a significant relationship in the case of the Nigerian stock index and inflation rate. The DUM lag periods are positive and significantly associated with the recapitalization variables of Spain and the U.S. This commonality should be expected as both countries' recapitalization was in response to the global financial crisis.

\section{[INSERT TABLE 4 HERE]}

Table 5 provides the ARDL bounds test results which serve to confirm our VEC outcomes. The $F$-statistics confirmed the presence of cointegration among the entire countries' variables, except 
in the cases of Nigerian industrial production which returned an insignificant outcome. This position is in conformity with the Johansen cointegration outcome in Table 3, where both the trace and the maximum tests returned evidence of cointegration among all countries' variables. From Table 5, we can see that the recapitalization is negatively significant in determining the Malaysian lending and inflation rates and also, the Mexican inflation rate. This point may highlight reduction in lending rate and inflation due to banking recapitalization. Recapitalization negatively determined Nigerian industrial production, a point which unexpectedly suggests negative influence of recapitalization on the industrial production. Recapitalization reduces Spain stock market activities and increases same in the case of the U.S. Generally, the ARDL results are in conformity with the Johansen and VEC results. This helps to confirm our results, indicating that there is no problem of outcome agreement among the separate procedures. The above VEC outcome, as confirmed by the ARDL process, implies that there is cointegration and error correction among all countries' macroeconomic variables. These results suggest we could now proceed to apply our main GFEVD model, its associated IRF and the Toda-Yamamoto to determine the economic effectiveness of banking recapitalization.

\section{[INSERT TABLE 5 HERE]}

Table 6 presents the GFEVD results which are based on an autoregressive trend of the data series and the outcome is divided into panels A, B, C, D and E which represents banking recapitalization variance decompositions for Malaysia, Mexico, Nigeria, Spain and the US, respectively. The table reveals that the Standard Error (SE) of the forecast goes up with increase in the period forecast. Thus, the SE increases as the relevance of each variable's lag period in predicting its period ahead declines. Hence, in order not to lose too much information, decompositions of variables are presented in each series relating to 8 periods (i.e., 8 quarters) ahead. Again, given the dynamic 
nature of the GFEVD model, a cautious interpretation of outcomes leading to economic relevance of banking recapitalization is presented from the model.

Throughout the estimated periods and in all of the countries' panels, recapitalization variables accounted for the highest number of forecast error variations. However, this degree of dominance was more in the case of Malaysia, Mexico and Nigeria. In the case of Spain and the US (beginning from the third period), other variables especially the inflation rate started becoming significant in accounting for the forecast error. ${ }^{14}$ These outcomes may underscore the diversified nature of developed economies, given the changing relevance of their industrial sector with the passage of time.

\section{[INSERT TABLE 6 HERE]}

As the main focus of this paper is to understand the effectiveness of banking recapitalization on the economies of regulation compelled recapitalizing countries, the impulse response function (IRF) method is implemented. The effect of banking recapitalization is mainly tracked through the responses of recapitalizing countries' macroeconomic variables to innovations in recapitalization variables. Accumulated responses were examined for 40 periods which translates into 10 years of forecast and which allows the analysis of short-run and long-run effects. Figures 1-5 report the accumulated impulse responses of recapitalizing countries' macroeconomic variables to innovations due to recapitalization.

\footnotetext{
${ }^{14}$ The dominance of banking recapitalization variables of the three developing economies (i.e., Malaysia, Mexico and Nigeria) included in the sample remained more long lasting in accounting for variations as compared to those of the developed countries (i.e., Spain and USA).
} 
Figure 1 explicitly tracks the response of the Malaysian macroeconomic variables to recapitalization. It can be seen that only stock market index responded to recapitalization with a steady rise up until the $40^{\text {th }}$ period. Industrial production, as well as lending, exchange and inflation rates all responded to recapitalization by falling steadily and consistently up until the $40^{\text {th }}$ period. The falling pattern of inflation rate was steadier in the short-run and long-run. Lending rates witnessed a faster fall from left to right, both in the short-run and long-run. This is not surprising as shock to the economy owing to banking recapitalization is expected to lower lending rates.

\section{[INSERT FIGURES 1-5 HERE]}

Figure 2 is the accumulated response of Mexico's macroeconomic variables to innovations due to banking recapitalization. Stock index, industrial production and exchange rate all responded to recapitalization with a steady rise, however, the pattern of the rise differs between the three variables. In the short-run, industrial production responded to banking recapitalization with a sharp and fast rise. Inflation and lending rates dropped sharply both in the short-run and long-run; these results are as expected and they validate the findings of the GFEVDs above.

Figure 3 examines the effect of banking recapitalization on Nigeria's macroeconomic variables. Stock index, industrial production, as well as lending and inflation rates cumulatively fell in the short-run through to the long-run as expected. In contrast, the exchange rate had an opposite reaction to recapitalization as the variable responded with steady rise in the short-run and in the long-run began to rise disproportionately and never came down. Surprisingly, lending rate fell in the first four periods and then began to rise sharply in the fifth period, a trend which defers from other countries' sample and in defiance of theoretical expectation (Berger and Bouwman, 2013). Explanation of this difference in reaction may be due to the Nigerian banking system witnessing 
a post-recapitalization period with the creation of toxic and subprime loans usually charged at very high interest rates. Behavioural issues which flourished due to the lack of effective regulatory environment may further explain this contrast.

Figure 4 shows the reaction of the Spanish macroeconomic variables to banking recapitalization. Stock index, industrial production and interest rate responses in the short-run were similar as they all clustered around zero up to period 4 when they started to rise at different rates through the long-run. Lending and exchange rates fell down sharply in a similar manner both in the short-run and long-run. Figure 5 captures the reaction of the U.S. macroeconomic variables to banking recapitalization. Both stock index and lending rates responded in a similar manner with steady fall in the short-run and remained same in the long-run. Inflation and exchange rates took a steady rise in a near similar manner both in the short-run and long-run. Industrial production fell swiftly in the short-run and attained its lowest point in period 11 before commencing a slow rise through the long-run. This could be attributed to the saturated nature of the economy with little or no room for expansion as seen by the initial rise in inflation. Also, the depressed economic condition made possible by the economic crisis might have contributed.

Table 7 reports the Toda-Yamamoto results which seek to understand the causal effect of respective variables (i.e., the direction of causality). In panel A, we have the Malaysian results which shows that the M-Wald test statistics between Malaysian recapitalization and inflation rate is significant, a result which seems to suggest that recapitalization causes inflation in the Malaysian economy. This outcome could be expected given that banking recapitalization increases access to funds to economic agents. Another suggestion may be that the Malaysian economy failed 
to channel the increased capital into productive use. Also, we have significant relationships between stock index and industrial production; lending rate and stock index; industrial production and lending rate; exchange rate and stock index; as well as exchange rate and lending rate, with the first variable usually causing the later. Panel B, Table 7 presents the Mexican results. Banking recapitalization causes stock market index. While this could be expected given the ability of banking recapitalization to increase stock market activities through increased capital made available by banks. Recapitalization also causes exchange rates, an outcome which may suggest element of capital flight, as economic agents may be borrowing to invest abroad or suggesting that recapitalization is pushing the economy towards import dependence. We also have a significant relationship between stock market index and lending rates; stock market index and exchange rate; lending rates and industrial production; lending rates and exchange rates; as well as industrial production and stock index.

The case of Nigeria is presented in Panel C Table 7 where we found recapitalization not to cause any of the macroeconomic variables as we fail to find any significant relationship. However, we found causality running from stock exchange to recapitalization, industrial production and exchange rate variables. Panel D Table 7 presents Span results, where we found causal relationships running from recapitalization to industrial production, exchange rate and inflation rate, thus suggesting banking recapitalization causing the later variables. On the opposite site, we found recapitalization being caused by lending rates, industrial production and exchange rates. Finally, Panel E Table 7 has the US results which suggests that recapitalization causes stock index, lending rates, industrial production and exchange rates. These results should be expected as recapitalization tends to influence the major macroeconomic activity of the US economy. 


\section{[INSERT TABLE 7 HERE]}

In summary, the economic effectiveness of banking recapitalization, examined through the GFEVDs and IRF models in addition to the T-Y procedure, shows consistent results in both models. A significant finding in both models is the similarity of reactions in macroeconomic variables of developing economies on the one hand and for developed economies on the other. For the developing economies of Malaysia, Mexico and Nigeria, a common feature is noted with regards to the reaction of their industrial production to banking recapitalization. This relates to the existence of spare capacity, which should lead to expansive investment activities, leveraging on the resulting falling lending rates. As for the developed economies of Spain and the U.S., notwithstanding the absence of spare capacity, banking recapitalization effects resulted in providing them with an opportunity to stabilize their banking system and the economy in general.

\section{Implications and Conclusions}

In this paper, we have examined the wider economic effectiveness of banking recapitalization through the reactions of macroeconomic variables in five economies. Our findings show that the macroeconomic variables in these economies have reacted to banking recapitalization in similar manner. However, the similarities reflect different divides, with a prominence of similar behaviour for macroeconomic variables of developed countries on the one hand, and also, a similar behaviour for the variables of developing countries on the other hand. In this instance, we found that all of the developing economies in the sample responded to recapitalization with a rise in industrial production. However, in the case of the developed economies, there was a fall in industrial production. Specifically, while many similarities were found in the reaction of the USA and Spanish variables to banking recapitalization, yet, the variables of Malaysia, Mexico and Nigeria were found to exhibit similar reactions to each other. 
These findings have implications for the literature on banking recapitalization, and for banks operating in different international business environments. For example, banking recapitalization, which mainly operates on the basis of meeting up with capital adequacy requirement as stipulated in the Basel accords (Bank for International Settlements, 1988; 2001; 2011; 2013), is thought to improve banks' resilience to risk. This is expected to ultimately enhance the efficient discharge of the financial intermediation role of the banking sector. One of the findings of this paper is the ability of banking recapitalization to lower banks' lending rates in all examined economies. While this outcome is expected, it should be equated with a similar capacity to borrow and invest for efficient economic impact. In relation to this, all developing economies in the sample responded to recapitalization with a rise in industrial production. However, in the case of the developed economies, there was a fall in industrial production. While these occurrences may be attributed to the comparative spare capacity of the developing economies, the developed economies could equally be reacting to the reduction in economic activities due to economic crisis. This is given that our data sample covered financial and economic crises periods, i.e., the 1997 Asian financial crisis and the 2007-2008 global financial and macroeconomic crises.

Therefore, this paper has succeeded in highlighting how crucial a strong capital is to the survival of the banking system of both developed and developing countries, during normal and crisis times. One insight that has become more apparent, in the case of the developing countries in our sample, is the potential lack of accompanying regulatory support in the aftermath of recapitalization. For instance, the Nigerian lending rates reacted to recapitalization with a continuous rise, as the country experienced the creation of large scale subprime loans attributable to (irrational) behavioral tendencies. This may be connected to the behavioral findings relating to the postbanking recapitalization era in both Malaysian and Mexican economies as Sufian and Habibullah 
(2013) and Maudos and Solís (2011), respectively, found. This may further imply that a review of the regulatory framework, with increased emphasis on supervision and good corporate governance practice should accompany bank recapitalization.

Another salient concern which may precipitate behavioural issues is connected to the gap in the implementation of the Basel regulations. For instance, the Basel III (Bank for International Settlements, 2011; 2013) is not coming into effect as a replacement of the existing Basel II until 2019. This may suggest that the Basel regulatory standards are catch-up tools, which are at best reactionary than proactive. Given the scale of behavioral issues especially surfacing in the aftermath of banking recapitalization, as evident in this study, it is important to point here that recapitalization alone may not necessarily provide the solution to risk-based problems. Managerial competence, discipline, increased surveillance, good corporate governance practice and coordinated institutional regulation are equally important. A further finding in this paper is that banking recapitalization motivated by market forces produces a different outcome to the one forced by regulators. Recapitalization carried out based on market expectations will have the tendency to influence economic activities through increased demand for loans. However, regulation compelled recapitalization may encourage behavioural issues.

Future studies should recognize this divide and examine the outcome of each effect on the economy. Other alternatives may be to study the reactions of economies with expected similar traits to banking recapitalization. For example, international business scholars may examine bank recapitalization in major emerging economies such as; Brazil, Russia, India, China and South Africa, Mexico, Indonesia, Nigeria and Turkey, with a consideration of their economic integration 
potentials in extending the current paper. Also, similarities among developed countries under suitable common criteria like the G7 and OECD economies among others could be explored.

We provide implications for international business research, practice and policy by highlighting the need for countries adopting the Basel capital adequacy framework to pay attention to the state of their economies, the supporting regulatory mechanisms (in place to check behavioural issues) and their comparative spare capacities. This is not only important for policy makers but also international businesses occupying multiple regulatory spaces in the global banking system. Unlike prior studies which mainly focussed on individual countries, our data has an international spread, which enables us to contribute a comparative perspective to the examination of the wider economic implication of banking recapitalization on the productive sector. 


\section{References}

Adegbite, E. (2015). Good corporate governance in Nigeria: antecedents, propositions and peculiarities. International Business Review 24(2): 319-330.

Angelini, P., Neri, S., and Panetta, F. (2014). The interaction between capital requirements and monetary policy. Journal of Money, Credit and Banking, 46(6), 1073-1112.

Angeloni, I., and Faia, E. (2013). Capital regulation and monetary policy with fragile banks. Journal of Monetary Economics, 60(3), 311-324

Apergis, N., Fafaliou, I. and Polemis, M.L. (2016). New evidence on assessing the level of competition in the European Union banking sector: a panel data approach. International Business Review, 25(1), 395-407.

Bank for International Settlements (1988). International Convergence of Capital Measurement and Capital Standards. Secretariat of the Basel Committee on Banking Supervision, Basel: Bank for International Settlements.

Bank for International Settlements (2001). The New Basel Accord: an Explanatory Note. Secretariat of the Basel Committee on Banking Supervision, Basel: Bank for International Settlements.

Bank for International Settlements (2011). Basel III: A global regulatory framework for more resilient banks and banking systems. Secretariat of the Basel Committee on Banking Supervision, Basel: Bank for International Settlements.

Bank for International Settlements (2013). Basel III: The Liquidity Coverage Ratio and liquidity risk monitoring tools. Secretariat of the Basel Committee on Banking Supervision, Basel: Bank for International Settlements.

Bank for International Settlements (2014). Assessment of Basel III regulations - European. Secretariat of the Basel Committee on Banking Supervision, Basel: Bank for International Settlements.

Bank of Spain (2015). The restructuring of the banking sector in Spain. Available at: < http://www.bde.es/bde/en/secciones/prensa/infointeres/reestructuracion/>. (accessed 05/06/2014).

Barrios, V. E., and Blanco, J. M. (2003). The effectiveness of bank capital adequacy regulation: A theoretical and empirical approach. Journal of Banking and Finance, 27(10), 1935-1958.

Berger, A. N., and Bouwman, C. H. (2013). How does capital affect bank performance during financial crises? Journal of Financial Economics, 109(1), 146-176.

Central Bank of Malaysia (2002). Consolidation of the Banking Sector. Available at: < http://www.bnm.gov.my/?ch=en_press\&pg=en_press_all\&ac=282\&lang=en $>$. (accessed 05/06/2014).

Central Bank of Nigeria (2004). Consolidating the Nigerian Banking Industry to Meet the

Development Challenges of the $21^{\text {st }}$ Century. Available

at: $<$ http://www.cbn.gov.ng/OUT/SPEECHES/2004/GOVADD-6JUL.PDF $>$ (accessed

01/11/2014)

Central Bank of Nigeria (2011). Public Statement on the Recapitalization of Eight Nigerian Banks. Available at:

<https://www.proshareng.com/admin/upload/reports/PressStmtRescuedBanks100611.pdf $>$ (accessed 01/11/2014).

Central Bank of Nigeria (2015), 'Reserve Management' Available at: <http://www.cenbank.org/IntOps/ReserveMgmt.asp>. (accessed 09/03/2016). 
Dell'Ariccia, G., Detragiache, E., and Rajan, R. (2008). The real effect of banking crises. Journal of Financial Intermediation, 17(1), 89-112.

Demirgüç-Kunt, A., Detragiache, E., and Merrouche, O. (2013). Bank capital: lessons from the financial crisis. Journal of Money, Credit and Banking, 45(6), 1147-1164.

Demirgüç-Kunt, A., Feyen, E., and Levine, R. (2012). The evolving importance of banks and securities markets. The World Bank Economic Review, 27(3), 476-490.

Eisenhardt, K.M (1989). Building theories from case study research. Academy of Management Review, 4, 532-550.

Engle, R. F. and Granger, C. W. J. (1987). Co-integration and error correction: representation, estimation, and testing. Econometrica, 55(2), 251-276.

Francis, W. B., and Osborne, M. (2012). Capital requirements and bank behavior in the UK: Are there lessons for international capital standards? Journal of Banking and Finance, 36(3), 803-816.

Gonzalez-Aguado, C. and Suarez, J. (2015). Interest rates and credit risk. Journal of Money, Credit and Banking, 47(2-3), 445-480.

Gonzalo, J. and Granger, C.W.J. (1995). Estimation of common long-memory components in cointegrated systems. Journal of Business and Economic Statistics, Vol. 13, 27-36.

Johansen, S. (1988), Statistical analysis of cointegration vectors. Journal of Economic Dynamics and Control, 12 (2-3), 231-254.

Markman, G.M. and Venzin, M. (2014). Resilience: lessons from banks that have braved the economic crisis-and from those that have not. International Business Review, 23, 10961107.

Maudos, J., and Solís, L. (2011). Deregulation, liberalization and recapitalization of the Mexican banking system: effects on competition. Journal of International Money and Finance, 30(2), 337-353.

Montes, C.P. (2014). The effect on competition of banking recapitalization following the financial crisis of 2008. Journal of Banking and Finance, 43, 124-136.

Payne, R. L., and Mansfield, R. (1973). Relationships of perceptions of organisational climate to organisational structure, context and hierarchical position. Administrative Science Quarterly, 18, 515-526.

Perron, P. and Vogelsang, T.J. (1992). Nonstationarity and level shifts with an application to purchasing power parity, Journal of Business \& Economic Statistics, 10, 301-320.

Pesaran, H. H. and Shin, Y. (1998). Generalized impulse response analysis in linear multivariate models. Economics Letters, 58(1), 17-29.

Pesaran, M. H., and Timmermann, A. (2007). Selection of estimation window in the presence of breaks. Journal of Econometrics, 137(1), 134-161.

Pesaran, M.H., Shin, Y., Smith, R.J. (2001). Bounds testing approaches to the analysis of level relationships, Journal of Applied Econometrics, 16, 289-326.

Repullo, R., and Suarez, J. (2013). The procyclical effects of bank capital regulation. Review of Financial Studies, 26(2), 452-490.

Sims, C. (1980). Macroeconomics and reality. Econometrica, 48(1), 1-48.

Sufian, F., and Habibullah, M. S. (2013). Financial sector recapitalization and competition in Malaysia: an application of the Panzar-Rosse method. Journal of Economic Studies, 40(3), 390-410.

Toda, H.Y. and Yamamoto, H. (1995). Statistical inference in vector autoregressions with possibly integrated processes. Journal of Econometrics, 66, 225-250.

VanHoose, D. (2007). Theories of bank behavior under capital regulation. Journal of Banking and Finance, 31(12), 3680-3697. 
World Bank (2015). World Development Indicators: Structure of output. Available at: <http://wdi.worldbank.org/table/4.2\#>. (accessed 10/10/2015).

Yildirim, H. S., and Philippatos, G. C. (2007). Restructuring, recapitalization and competition in Latin American banking markets. Journal of Banking and Finance, 31(3), 629-639. 
Table 1: Descriptive Statistics

\begin{tabular}{|c|c|c|c|c|c|c|}
\hline Country & Series & Mean & Median & Maximum & Minimum & Std. Dev. \\
\hline \multirow{6}{*}{ Malaysia } & $R E C A P$ & 0.09 & 0.00 & 1.00 & 0.00 & 0.28 \\
\hline & $\boldsymbol{M A S I}_{t}$ & 1041.36 & 952.72 & 1882.71 & 373.52 & 411.10 \\
\hline & $M^{\prime} A I P_{t}$ & 78.95 & 80.90 & 124.80 & 28.60 & 27.69 \\
\hline & $M A L R_{t}$ & 7.10 & 6.72 & 12.27 & 5.51 & 1.24 \\
\hline & $M A I R_{t}$ & 2.81 & 2.86 & 8.40 & -2.28 & 1.44 \\
\hline & $M A E R_{t}$ & 3.30 & 3.31 & 4.45 & 2.44 & 0.52 \\
\hline \multirow{6}{*}{ Mexico } & RECAP & 0.08 & 0.00 & 1.00 & 0.00 & 0.27 \\
\hline & $\operatorname{MESI}_{t}$ & 19003.29 & 12676.90 & 45881.08 & 1832.83 & 15542.00 \\
\hline & $M E I P t$ & 91.29 & 92.86 & 108.10 & 65.37 & 11.85 \\
\hline & $M E L R_{t}$ & 13.91 & 8.11 & 71.02 & 3.30 & 13.44 \\
\hline & $M E I R_{t}$ & 9.23 & 4.77 & 48.70 & 2.28 & 9.86 \\
\hline & $M E E R_{t}$ & 79.81 & 77.54 & 126.43 & 57.29 & 12.27 \\
\hline \multirow{6}{*}{ Nigeria } & $R E C A P$ & 0.10 & 0.00 & 1.00 & 0.00 & 0.30 \\
\hline & $N S I_{t}$ & 210.61 & 188.75 & 749.32 & 49.71 & 153.11 \\
\hline & $N I P_{t}$ & 4693167.00 & 142071.40 & 18745360.00 & 88137.80 & 7143162.00 \\
\hline & $N L R_{t}$ & 18.60 & 17.85 & 26.25 & 13.86 & 2.51 \\
\hline & $N I R_{t}$ & 12.02 & 10.72 & 47.25 & -3.13 & 9.07 \\
\hline & $N E R_{t}$ & 130.05 & 130.05 & 199.26 & 75.72 & 30.78 \\
\hline \multirow{6}{*}{ Spain } & $R E C A P$ & 0.08 & 0.00 & 1.00 & 0.00 & 0.27 \\
\hline & $S S I_{t}$ & 778.69 & 828.14 & 1691.55 & 204.75 & 383.86 \\
\hline & $S I P_{t}$ & 105.31 & 100.64 & 128.05 & 86.03 & 12.44 \\
\hline & $S L R_{t}$ & 6.19 & 4.92 & 14.93 & 3.02 & 3.46 \\
\hline & $S I R_{t}$ & 3.26 & 3.27 & 7.00 & -1.07 & 1.70 \\
\hline & $S E R_{t}$ & 133.77 & 128.85 & 191.60 & 95.02 & 22.84 \\
\hline \multirow{6}{*}{$\boldsymbol{U S A}$} & $R E C A P$ & 0.08 & 0.00 & 1.00 & 0.00 & 0.27 \\
\hline & $U S S I_{t}$ & 9519.46 & 10305.96 & 17929.99 & 2452.48 & 4267.35 \\
\hline & $U_{S I P}$ & 89.78 & 94.29 & 106.28 & 63.08 & 13.54 \\
\hline & $U S L R_{t}$ & 14.32 & 13.60 & 18.28 & 11.82 & 2.05 \\
\hline & USIRt & 2.51 & 2.65 & 6.22 & -1.62 & 1.30 \\
\hline & USER & 1.65 & 1.61 & 2.04 & 1.42 & 0.15 \\
\hline
\end{tabular}

Notes: MA, ME, N, S and US represent Malaysia, Mexico, Nigeria, Spain and USA respectively. Stock Market Indices, Lending Rates, Industrial Production, Exchange Rates and Inflation Rates are respectively represented with the following acronyms: SI, LR, IP, ER and IR. MASI, MALR, MAIP, MAER and MAIR; MESI, MELR, MEIP, MEER and MEIR; NSI, NLR, NIP, NER and NIR; SSI, SLR, SIP, SER and SIR; USSI, USLR, USIP, USER and USIR, represent the respective countries under consideration with the corresponding variable. See footnote 12 for the explanation of RECAP variable construction. 
Table 2A: ADF Test (Intercept and trend)

\begin{tabular}{|c|c|c|c|c|c|c|}
\hline & \multicolumn{3}{|c|}{ Test at Levels } & \multicolumn{3}{|c|}{ Test at First Differences } \\
\hline Country & Series & $\begin{array}{c}\text { Lag } \\
\text { length }\end{array}$ & $\begin{array}{c}\text { ADF } \\
t \text {-stat }\end{array}$ & Series & $\begin{array}{c}\text { Lag } \\
\text { length }\end{array}$ & $\begin{array}{c}\text { ADF } \\
t \text {-stat }\end{array}$ \\
\hline \multirow{5}{*}{ Malaysia } & MASI $_{t}$ & 0 & -2.3095 & $\Delta M A S I_{t}$ & 0 & $-10.748^{* *}$ \\
\hline & MAIP $_{t}$ & 0 & -2.4643 & $\Delta M A I P_{t}$ & 5 & $-5.5676^{* *}$ \\
\hline & MALRt & 3 & -3.3759 & $\triangle M A L R_{t}$ & 1 & $-7.6381^{* *}$ \\
\hline & MAIRt & 4 & $-3.1797^{* *}$ & $\triangle M A I R_{t}$ & N/A & N/A \\
\hline & $M A E R_{t}$ & 0 & -1.7381 & $\triangle M A E R_{t}$ & 0 & $-9.8811^{* *}$ \\
\hline \multirow{5}{*}{ Mexico } & $M_{E S I_{t}}$ & 1 & -2.2423 & $\Delta M E S I_{t}$ & 1 & $-7.9313^{* *}$ \\
\hline & $\operatorname{MEIP}_{t}$ & 1 & -2.8261 & $\Delta M E I P_{t}$ & 0 & $-5.7539^{* * *}$ \\
\hline & MELRt & 10 & -1.7508 & $\Delta M E L R_{t}$ & 11 & $-7.7125^{* *}$ \\
\hline & MEIRt & 1 & $-4.2383^{* *}$ & $\Delta M E I R_{t}$ & N/A & N/A \\
\hline & $\operatorname{MEER}_{t}$ & 0 & -2.5088 & $\Delta M E E R_{t}$ & 0 & $-10.126^{* *}$ \\
\hline \multirow{5}{*}{ Nigeria } & NSI $I_{t}$ & 4 & -1.7570 & $\Delta N S I_{t}$ & 3 & $-5.2269^{* *}$ \\
\hline & $N I P_{t}$ & 0 & -1.8208 & $\Delta N I P_{t}$ & 0 & $-8.8130^{* *}$ \\
\hline & $N L R_{t}$ & 0 & -1.8254 & $\Delta N L R_{t}$ & 0 & $-8.0803^{* *}$ \\
\hline & $N I R_{t}$ & 2 & $-4.5601^{* *}$ & $\Delta N I R_{t}$ & N/A & N/A \\
\hline & $N E R_{t}$ & 0 & 0.4331 & $\Delta N E R_{t}$ & 0 & $-5.0664^{* *}$ \\
\hline \multirow{5}{*}{ Spain } & $S S I_{t}$ & 1 & -2.0553 & $\Delta S S I_{t}$ & 0 & $-7.4503^{* *}$ \\
\hline & $S I P_{t}$ & 1 & -1.4099 & $\Delta S I P_{t}$ & 0 & $-5.2236^{* *}$ \\
\hline & $S L R_{t}$ & 1 & -2.9597 & $\Delta \boldsymbol{S L} \boldsymbol{R}_{t}$ & 3 & $-6.1584^{* *}$ \\
\hline & $\operatorname{SIR}_{t}$ & 1 & $-3.5467^{*}$ & $\Delta \operatorname{SIR}_{t}$ & N/A & N/A \\
\hline & $S E R_{t}$ & 1 & -2.0219 & $\Delta \boldsymbol{S E} \boldsymbol{R}_{t}$ & 0 & $-7.7094^{* *}$ \\
\hline \multirow{5}{*}{$\boldsymbol{U S A}$} & USSI & 4 & -2.301 & $\Delta U S S I_{t}$ & 0 & $-10.353^{* *}$ \\
\hline & $\boldsymbol{U S I P}_{t}$ & 1 & -2.3404 & $\Delta \boldsymbol{U S I P}_{t}$ & 1 & $-4.708^{* *}$ \\
\hline & $U S L R_{t}$ & 0 & -1.7451 & $\Delta \boldsymbol{U S L R} \boldsymbol{R}_{t}$ & 0 & $-8.6265^{* *}$ \\
\hline & USIRt $_{t}$ & 5 & -3.9847 & $\Delta \boldsymbol{U S I R}_{t}$ & 4 & $-5.1854^{* *}$ \\
\hline & USER $_{t}$ & 2 & -2.3630 & $\Delta \boldsymbol{U S E R _ { t }}$ & 1 & $-8.8911^{* *}$ \\
\hline
\end{tabular}

Notes: Variables on the left panel are presented in levels whereas the variables on the right panel are presented in first differences. Tests (including lag length) were determined based on Schwarz information criteria (SC). The asterisk ${ }^{*}$ indicates statistical significance at the $5 \%$ level, ${ }^{* *}$ indicates statistical significance at the $1 \%$ level. N/A refers to 'not applicable', and it is being used to indicate that the test is not necessary as the variable is already stationary at level. Recapitalization (RECAP) unit root was also tested in the instances of all countries, they were found to be nonstationary at level and stationary at first difference. See also notes in Table 1.
Table 2B: P-P Test (Intercept and trend)

\begin{tabular}{|c|c|c|c|c|c|c|}
\hline \multirow[b]{2}{*}{ Country } & \multicolumn{3}{|c|}{ Test at Levels } & \multicolumn{3}{|c|}{ Test at First Differences } \\
\hline & Series & $\begin{array}{l}\text { Band- } \\
\text { width }\end{array}$ & $\begin{array}{c}\text { P-P } \\
t \text {-stat }\end{array}$ & Series & $\begin{array}{l}\text { Band- } \\
\text { width }\end{array}$ & $\begin{array}{c}\text { P-P } \\
t \text {-stat }\end{array}$ \\
\hline \multirow{5}{*}{ Malaysia } & MASI $_{t}$ & 2 & -2.3343 & $\Delta M A S I_{t}$ & 2 & $-10.742^{* * *}$ \\
\hline & $M_{A I P}$ & 6 & -2.4093 & $\triangle M A I P_{t}$ & 5 & $-10.328^{* *}$ \\
\hline & $M A L R_{t}$ & 4 & -2.8530 & $\triangle M A L R_{t}$ & 2 & $-7.2534^{* * *}$ \\
\hline & $M A I R_{t}$ & 22 & $-3.0770^{*}$ & $\triangle M A I R_{t}$ & N/A & N/A \\
\hline & MAER $\boldsymbol{R}_{t}$ & 1 & -1.7761 & $\triangle M A S I_{t}$ & 2 & $-9.8903^{* * *}$ \\
\hline \multirow{5}{*}{ Mexico } & $M E S I_{t}$ & 5 & -1.9708 & $\Delta M E S I_{t}$ & 11 & $-8.1499^{* *}$ \\
\hline & $\mathrm{MEIP}_{t}$ & 3 & -2.2216 & $\Delta M E I P_{t}$ & 2 & $-5.8267^{* *}$ \\
\hline & MELRt & 4 & -3.7441 & $\triangle M E L R_{t}$ & 3 & $-9.8391^{* *}$ \\
\hline & $M E I R_{t}$ & 0 & -1.9983 & $\Delta M E I R_{t}$ & 18 & $-4.2246^{* * *}$ \\
\hline & $M E E R_{t}$ & 4 & -2.7701 & $\triangle M E E R_{t}$ & 1 & $-4.7867^{* *}$ \\
\hline \multirow{5}{*}{ Nigeria } & $N S I_{t}$ & 5 & -1.9901 & $\Delta N S I_{t}$ & 5 & $-6.3377^{\text {** }}$ \\
\hline & $N I P_{t}$ & 0 & -1.8208 & $\Delta N I P_{t}$ & 2 & $-8.8040^{* *}$ \\
\hline & $N L R_{t}$ & 4 & -2.2123 & $\Delta N L R_{t}$ & 4 & $-8.1832^{* *}$ \\
\hline & $N I R_{t}$ & 4 & $-4.4975^{* *}$ & $\Delta N I R_{t}$ & N/A & N/A \\
\hline & $N E R_{t}$ & 3 & 1.0281 & $\Delta N E R_{t}$ & 2 & $-4.8007^{* *}$ \\
\hline \multirow{5}{*}{ Spain } & $S S I_{t}$ & 4 & -1.9781 & $\Delta S S I_{t}$ & 1 & $-7.4529^{* *}$ \\
\hline & $S I P_{t}$ & 5 & -2.1902 & $\Delta \boldsymbol{S I P}_{t}$ & 3 & $-5.3604^{* *}$ \\
\hline & $S L R_{t}$ & 4 & -2.3126 & $\Delta \boldsymbol{S L R} \boldsymbol{R}_{t}$ & 6 & $-5.4084^{* *}$ \\
\hline & $S I R_{t}$ & 10 & -2.6233 & $\Delta S I R_{t}$ & 33 & $-8.2589^{* *}$ \\
\hline & $S E R_{t}$ & 2 & -1.7471 & $\Delta S E R_{t}$ & 4 & $-7.6693^{* *}$ \\
\hline \multirow{5}{*}{$\boldsymbol{U S A}$} & USSI $_{t}$ & 4 & -2.301 & $\Delta \boldsymbol{U S S I}_{t}$ & 2 & $-10.352^{* *}$ \\
\hline & $U_{S I P}$ & 5 & -1.4975 & $\Delta U_{S I P}$ & 6 & $-3.8848^{*}$ \\
\hline & $U S L R_{t}$ & 4 & -2.2385 & $\Delta \boldsymbol{U} \boldsymbol{S L} \boldsymbol{R}_{t}$ & 4 & $-8.7463^{* *}$ \\
\hline & $U_{S I R_{t}}$ & 32 & -2.8932 & $\Delta \boldsymbol{U S I R}_{t}$ & 34 & $-10.751^{\text {** }}$ \\
\hline & USER $_{t}$ & 4 & -2.4449 & $\Delta U S E R_{t}$ & 15 & $-7.3949^{* *}$ \\
\hline
\end{tabular}

Notes: Tests bandwidth was determined based on Newey-West estimator. All other provisions are same as Table $2 \mathrm{~A}$. 
Table 2C: KPSS Test (Intercept and trend)

\begin{tabular}{|c|c|c|c|c|c|c|}
\hline & \multicolumn{3}{|c|}{ Test at Levels } & \multicolumn{3}{|c|}{ Test at First Differences } \\
\hline Country & Series & $\begin{array}{l}\text { Band- } \\
\text { Width }\end{array}$ & $\begin{array}{l}\text { KPSS } \\
t \text {-stat }\end{array}$ & Series & $\begin{array}{l}\text { Band- } \\
\text { width }\end{array}$ & $\begin{array}{c}\text { ADF } \\
t \text {-stat }\end{array}$ \\
\hline \multirow{5}{*}{ Malaysia } & MASI $_{t}$ & 8 & 0.2159 & $\Delta M A S I_{t}$ & 3 & $0.0420^{* *}$ \\
\hline & MAIP $_{t}$ & 8 & 0.2048 & $\triangle M A I P_{t}$ & 5 & $0.0414^{* *}$ \\
\hline & $M A L R_{t}$ & 8 & 0.1000 & $\triangle M A L R_{t}$ & 3 & $0.0561^{* *}$ \\
\hline & MAIRt & 4 & $0.1180^{* *}$ & $\triangle M A I R_{t}$ & N/A & N/A \\
\hline & $M A E R_{t}$ & 8 & 0.1984 & $\triangle M A E R_{t}$ & 2 & $0.0848^{* *}$ \\
\hline \multirow{5}{*}{ Mexico } & $\mathrm{MESI}_{t}$ & 8 & 0.2815 & $\Delta M E S I_{t}$ & 7 & $0.0629^{* *}$ \\
\hline & $\operatorname{MEIP}_{t}$ & 7 & 0.1175 & $\Delta M E I P_{t}$ & 3 & $0.0382^{* *}$ \\
\hline & $\operatorname{MELR} \boldsymbol{R}_{t}$ & 6 & 0.1616 & $\triangle M E L R_{t}$ & 3 & $0.0420^{* *}$ \\
\hline & MEIRt & 7 & $0.0929^{*}$ & $\Delta M E I R_{t}$ & N/A & N/A \\
\hline & MEER $_{t}$ & 8 & 0.1531 & $\triangle M E E R_{t}$ & 3 & $0.0328^{* *}$ \\
\hline \multirow{5}{*}{ Nigeria } & $N S I_{t}$ & 6 & 0.1621 & $\Delta N S I_{t}$ & 4 & $0.0476^{* *}$ \\
\hline & $N I P_{t}$ & 6 & 0.2673 & $\Delta N I P_{t}$ & 2 & $0.0660^{* *}$ \\
\hline & $N L R_{t}$ & 6 & 0.1161 & $\Delta N L R_{t}$ & 4 & $0.0575^{* *}$ \\
\hline & $N I R_{t}$ & 5 & $0.0445^{* *}$ & $\Delta N I R_{t}$ & N/A & N/A \\
\hline & $N E R_{t}$ & 6 & 1.2283 & $\Delta N E R_{t}$ & 1 & $0.3932^{* *}$ \\
\hline \multirow{5}{*}{ Spain } & $S S I_{t}$ & 7 & 0.1636 & $\Delta S S I_{t}$ & 3 & $0.0578^{* *}$ \\
\hline & $S I P_{t}$ & 9 & 0.2538 & $\Delta \boldsymbol{S I P}_{t}$ & 5 & $0.0841^{* *}$ \\
\hline & $S L R_{t}$ & 9 & 0.2695 & $\Delta S L R_{t}$ & 4 & $0.0425^{* *}$ \\
\hline & $S I R_{t}$ & 7 & 0.1196 & $\Delta S_{I R}$ & 17 & 0.1278 \\
\hline & $S E R_{t}$ & 8 & 0.2000 & $\Delta S E R_{t}$ & 3 & 0.1093 \\
\hline \multirow{5}{*}{ USA } & $U_{S S I}$ & 8 & 0.1080 & $\Delta U S S I_{t}$ & 2 & $0.0605^{* *}$ \\
\hline & USIPt $_{t}$ & 8 & 0.2544 & $\Delta U_{S I P}$ & 5 & $0.0560^{* *}$ \\
\hline & $\boldsymbol{U S L R} \boldsymbol{R}_{t}$ & 8 & 0.1826 & $\Delta \boldsymbol{U S L R} \boldsymbol{R}_{t}$ & 4 & $0.0334^{* *}$ \\
\hline & USIR $_{t}$ & 5 & $0.0988^{*}$ & $\Delta \boldsymbol{U S I R}_{t}$ & N/A & N/A \\
\hline & USER & 8 & 0.1087 & $\Delta \boldsymbol{U} \boldsymbol{S E} \boldsymbol{R}_{t}$ & 9 & $0.0571^{* *}$ \\
\hline
\end{tabular}

Notes: Tests bandwidth was determined based on Newey-West estimator. See also notes in Table $2 \mathrm{~A}$
Table 2D: Breakpoint Test (Intercept Only)

\begin{tabular}{|c|c|c|c|c|c|c|}
\hline \multirow[b]{2}{*}{ Country } & \multicolumn{3}{|c|}{ Test at Levels } & \multicolumn{3}{|c|}{ Test at First Differences } \\
\hline & Series & $\begin{array}{l}\text { ADF } \\
t \text {-stat }\end{array}$ & $\begin{array}{l}\text { Break } \\
\text { period }\end{array}$ & Series & $\begin{array}{c}\text { ADF } \\
t \text {-stat }\end{array}$ & $\begin{array}{l}\text { Break } \\
\text { period }\end{array}$ \\
\hline \multirow{5}{*}{ Malaysia } & MASI $_{t}$ & -3.4838 & 2009Q1 & $\Delta M A S I_{t}$ & $-11.2711^{* *}$ & 1997Q3 \\
\hline & $M A I P_{t}$ & -2.2362 & 1999Q1 & $\triangle M A I P_{t}$ & $-11.0564^{* *}$ & 2009Q1 \\
\hline & $M A L R_{t}$ & $-6.2611^{* *}$ & 1998Q1 & $\triangle M A L R_{t}$ & N/A & N/A \\
\hline & $M A I R_{t}$ & $-5.2851^{* *}$ & 1998Q3 & $\Delta M A I R_{t}$ & N/A & N/A \\
\hline & $M A E R_{t}$ & -3.9064 & 1997Q2 & $\triangle M A E R_{t}$ & $12.2728^{* *}$ & 1997Q4 \\
\hline \multirow{5}{*}{ Mexico } & $\mathrm{MESI}_{t}$ & -2.3709 & 2005Q2 & $\Delta M E S I_{t}$ & $-8.7688^{* *}$ & 2008Q3 \\
\hline & $\operatorname{MEIP}_{t}$ & -2.1950 & 1996Q3 & $\Delta M E I P_{t}$ & $-6.4735^{* *}$ & 2009Q1 \\
\hline & $M E L R_{t}$ & $-4.3072^{*}$ & 1998Q4 & $\triangle M E L R_{t}$ & N/A & N/A \\
\hline & $M E I R t$ & $-5.0234^{* *}$ & 1999Q1 & $\Delta M E I R_{t}$ & N/A & N/A \\
\hline & $M E E R_{t}$ & $-5.1622^{* *}$ & 1995Q1 & $\triangle M E E R_{t}$ & N/A & N/A \\
\hline \multirow{5}{*}{ Nigeria } & $N S I_{t}$ & -2.9942 & 2009Q2 & $\Delta N S I_{t}$ & $-6.2146^{* *}$ & 2007Q4 \\
\hline & $N I P_{t}$ & $-18.331^{* *}$ & 2009Q4 & $\Delta N I P_{t}$ & N/A & N/A \\
\hline & $N L R_{t}$ & -3.7514 & 2002Q3 & $\Delta N L R_{t}$ & $-9.2214^{* *}$ & 2002Q4 \\
\hline & $N I R_{t}$ & $-6.0694^{* *}$ & 2005Q2 & $\Delta N I R_{t}$ & N/A & N/A \\
\hline & $N E R_{t}$ & -0.4990 & 2014Q3 & $\Delta N E R_{t}$ & $-8.8570^{* * *}$ & 2016Q1 \\
\hline \multirow{5}{*}{ Spain } & $S S I_{t}$ & -2.9043 & 1996Q3 & $\Delta S S I_{t}$ & $-8.2547^{* *}$ & 2008Q4 \\
\hline & $S_{P} P_{t}$ & -2.4336 & 2007Q4 & $\Delta S I P_{t}$ & $-7.4805^{* *}$ & 2008Q4 \\
\hline & $S L R_{t}$ & $-5.0327^{* *}$ & 1995Q4 & $\Delta \boldsymbol{S L R} \boldsymbol{R}_{t}$ & N/A & N/A \\
\hline & $\operatorname{SIR}_{t}$ & -3.7976 & 2008Q3 & $\Delta S_{I R}$ & $-8.2801^{* *}$ & 2008Q4 \\
\hline & $\mathrm{SER}_{t}$ & -2.6218 & 2001Q2 & $\Delta S E R_{t}$ & $-8.1032^{* *}$ & 2002Q3 \\
\hline \multirow{5}{*}{ USA } & USSI & -2.1073 & 2009Q1 & $\Delta U S S I_{t}$ & $-11.2355^{* *}$ & 2008Q4 \\
\hline & $U_{S I P}$ & -2.8615 & 1996Q1 & $\Delta \boldsymbol{U S I P}_{t}$ & $-5.7407^{* *}$ & 2009Q1 \\
\hline & $U S L R_{t}$ & -3.6758 & $2000 Q 4$ & $\Delta \boldsymbol{U S L R} \boldsymbol{R}_{t}$ & $-9.1760^{* * *}$ & 2003Q1 \\
\hline & $\boldsymbol{U S I R}_{t}$ & $-5.4147^{* *}$ & 2008Q3 & $\Delta \boldsymbol{U S I R _ { t }}$ & N/A & N/A \\
\hline & USER $\boldsymbol{R}_{t}$ & -3.1907 & 2009Q2 & $\Delta U \boldsymbol{S E R} \boldsymbol{R}_{t}$ & $-10.3507^{* *}$ & 2008Q4 \\
\hline
\end{tabular}

Notes: See also notes in Table 2A. 
Table 3: Cointegration Tests

\begin{tabular}{|c|c|c|c|c|c|c|c|c|}
\hline \multirow[b]{2}{*}{ Country } & \multicolumn{4}{|c|}{$\underline{\text { Panel A: Trace Test }}$} & \multicolumn{4}{|c|}{ Panel B: Max-Eigenvalue Test } \\
\hline & $H_{0}$ & $\begin{array}{c}\lambda_{\text {trace }} \\
\text { Stat }\end{array}$ & $\begin{array}{l}5 \% \\
\text { C.V. }\end{array}$ & $p$-value & $H_{0}$ & $\begin{array}{c}\lambda_{\max } \\
\text { Stat }\end{array}$ & $\begin{array}{c}5 \% \\
\text { C.V. }\end{array}$ & $p$-value \\
\hline \multirow{7}{*}{ Malaysia } & None * & 278.27 & 150.56 & 0.0000 & None $*$ & 82.02 & 50.60 & 0.0000 \\
\hline & At most $1 *$ & 196.25 & 117.71 & 0.0000 & At most $1 *$ & 56.09 & 44.50 & 0.0019 \\
\hline & At most $2 *$ & 140.16 & 88.80 & 0.0000 & At most $2 *$ & 51.40 & 38.33 & 0.0010 \\
\hline & At most $3 *$ & 88.76 & 63.88 & 0.0001 & At most $3 *$ & 37.48 & 32.12 & 0.0100 \\
\hline & At most $4 *$ & 51.28 & 42.92 & 0.0059 & At most $4 *$ & 30.46 & 25.82 & 0.0114 \\
\hline & At most 5 & 20.82 & 25.87 & 0.1872 & At most 5 & 10.72 & 19.39 & 0.5420 \\
\hline & At most 6 & 10.098 & 12.58 & 0.1228 & At most 6 & 10.10 & 12.52 & 0.1228 \\
\hline \multirow{7}{*}{ Mexico } & None $*$ & 618.14 & 150.55 & 0.0001 & None $*$ & 182.75 & 50.599 & 0.0000 \\
\hline & At most $1 *$ & 435.38 & 117.70 & 0.0000 & At most $1 *$ & 155.83 & 44.497 & 0.0000 \\
\hline & At most $2 *$ & 279.54 & 88.803 & 0.0000 & At most $2 *$ & 121.42 & 38.331 & 0.0000 \\
\hline & At most $3 *$ & 158.12 & 63.876 & 0.0000 & At most $3 *$ & 71.524 & 32.118 & 0.0000 \\
\hline & At most $4 *$ & 86.602 & 42.915 & 0.0000 & At most $4 *$ & 49.946 & 25.823 & 0.0000 \\
\hline & At most $5 *$ & 36.656 & 25.872 & 0.0016 & At most $5 *$ & 24.312 & 19.387 & 0.0088 \\
\hline & At most 6 & 12.343 & 12.517 & 0.0535 & At most 6 & 12.343 & 12.517 & 0.0535 \\
\hline \multirow{7}{*}{ Nigeria } & None * & 711.05 & 125.62 & 0.0001 & None $*$ & 221.21 & 46.23 & 0.0000 \\
\hline & At most $1 *$ & 489.84 & 95.75 & 0.0001 & At most $1 *$ & 209.15 & 40.08 & 0.0001 \\
\hline & At most $2 *$ & 280.69 & 69.82 & 0.0000 & At most $2 *$ & 111.55 & 33.88 & 0.0000 \\
\hline & At most $3 *$ & 169.14 & 47.86 & 0.0000 & At most $3 *$ & 79.77 & 27.58 & 0.0000 \\
\hline & At most $4 *$ & 89.37 & 29.80 & 0.0000 & At most $4 *$ & 67.31 & 21.13 & 0.0000 \\
\hline & At most $5 *$ & 22.07 & 15.49 & 0.0044 & At most $5 *$ & 18.80 & 14.26 & 0.0089 \\
\hline & At most 6 & 3.26 & 3.84 & 0.0710 & At most 6 & 3.26 & 3.84 & 0.0710 \\
\hline \multirow{7}{*}{ Spain } & None * & 365.61 & 125.62 & 0.0000 & None $*$ & 124.36 & 46.23 & 0.0000 \\
\hline & At most $1 *$ & 241.25 & 95.75 & 0.0000 & At most $1 *$ & 88.76 & 40.08 & 0.0000 \\
\hline & At most $2 *$ & 152.49 & 69.82 & 0.0000 & At most $2 *$ & 69.46 & 33.88 & 0.0000 \\
\hline & At most $3 *$ & 83.02 & 47.86 & 0.0000 & At most $3 *$ & 40.15 & 27.58 & 0.0007 \\
\hline & At most $4 *$ & 42.87 & 29.80 & 0.0009 & At most $4 *$ & 24.69 & 21.13 & 0.0151 \\
\hline & At most $5 *$ & 18.18 & 15.49 & 0.0192 & At most $5 *$ & 17.97 & 14.26 & 0.0124 \\
\hline & At most 6 & 0.22 & 3.84 & 0.6417 & At most 6 & 0.22 & 3.84 & 0.6417 \\
\hline \multirow{7}{*}{ USA } & None $*$ & 326.66 & 150.56 & $2.3 \mathrm{E}-18$ & None * & 108.22 & 50.60 & $3.5 \mathrm{E}-09$ \\
\hline & At most $1 *$ & 218.44 & 117.71 & $3.3 \mathrm{E}-14$ & At most $1 *$ & 69.87 & 44.50 & $1.4 \mathrm{E}-05$ \\
\hline & At most $2 *$ & 148.57 & 88.80 & $2.2 \mathrm{E}-08$ & At most $2 *$ & 50.31 & 38.33 & $1.4 \mathrm{E}-03$ \\
\hline & At most $3 *$ & 98.25 & 63.88 & 6.7E-06 & At most $3 *$ & 40.97 & 32.12 & $3.2 \mathrm{E}-03$ \\
\hline & At most $4 *$ & 57.28 & 42.92 & $1.0 \mathrm{E}-03$ & At most $4 *$ & 30.19 & 25.82 & $1.2 \mathrm{E}-02$ \\
\hline & At most $5 *$ & 27.09 & 25.87 & $3.5 \mathrm{E}-02$ & At most 5 & 16.50 & 19.39 & $1.3 \mathrm{E}-01$ \\
\hline & At most 6 & 10.59 & 12.52 & $1.0 \mathrm{E}-01$ & At most 6 & 10.59 & 12.52 & $1.0 \mathrm{E}-01$ \\
\hline
\end{tabular}

Notes; Co-integration tests model is based on each country's data series and recapitalization (RECAP) variable in addition to the dummy (DUM) applied as exogenous variable. The asterisk * indicates presence of co-integrating equation at the $5 \%$ level for both the trace and max-eigenvalue tests. $\lambda_{\max }$ tests the null hypothesis that the number of cointegrating vectors is " $\mathrm{r}$ " against the alternative hypothesis of " $\mathrm{r}+1$ ". $\lambda_{\text {trace }}$ tests the null hypothesis that the number of cointegrating vectors is equal to or less than " $r$ " against the alternative hypothesis of ">r". C.V. stands for critical value. 
Table 4: Vector Error Correction Model (VECM) Estimates

\begin{tabular}{|c|c|c|c|c|c|c|c|}
\hline Country & & $\triangle R E C A P_{t}$ & $\triangle M A S I_{t}$ & $\triangle M A I P_{t}$ & $\triangle M A L R_{t}$ & $\Delta M A I R_{t}$ & $\triangle M A E R_{t}$ \\
\hline \multirow{7}{*}{ Malaysia } & $\triangle R E C A P_{t-1}$ & {$[-0.04583]$} & {$[0.29313]$} & {$[-0.17689]$} & {$[0.17569]$} & {$[0.46224]$} & {$[0.03129]$} \\
\hline & $\Delta M A S I_{t-1}$ & [0.01320] & {$[-2.05671]^{*}$} & {$[-0.15134]$} & {$[0.35561]$} & {$[-0.63635]$} & {$[-1.37698]$} \\
\hline & $\Delta M A I P_{t-1}$ & {$[-1.00361]$} & {$[-0.34832]$} & {$[-1.29558]$} & {$[0.27635]$} & {$[-0.42628]$} & {$[-0.17243]$} \\
\hline & $\Delta M A L R_{t-1}$ & {$[-0.29413]$} & {$[-2.05358]^{*}$} & {$[-0.11713]$} & {$[2.31251]^{*}$} & [0.51327] & [0.92686] \\
\hline & $\Delta M A I R_{t-I}$ & [0.14583] & {$[-3.17035]^{*}$} & {$[-1.19089]$} & {$[0.63464]$} & {$[4.78163]^{*}$} & [0.93684] \\
\hline & $\Delta M A E R_{t-1}$ & [0.09393] & {$[-0.54538]$} & {$[-0.35994]$} & {$[-0.39934]$} & {$[-0.65369]$} & [-0.94499] \\
\hline & $D U M$ & {$[-0.07770]$} & {$[-3.35778]^{*}$} & {$[-2.30883]^{*}$} & {$[-0.40597]$} & [1.63907] & {$[2.54983]^{*}$} \\
\hline & & $\triangle R E C A P_{t}$ & $\Delta M E S I_{t}$ & $\Delta M E I P_{t}$ & $\triangle M E L R_{t}$ & $\Delta M E I R_{t}$ & $\Delta M E E R_{t}$ \\
\hline \multirow{7}{*}{ Mexico } & $\triangle R E C A P_{t-1}$ & {$[-0.32175]$} & {$[0.03355]$} & {$[-0.72917]$} & {$[-0.54872]$} & [0.11704] & {$[0.09957]$} \\
\hline & $\Delta M E S I_{t-1}$ & {$[-1.13121]$} & {$[1.98780]^{*}$} & {$[2.92809]^{*}$} & {$[-0.34103]$} & [0.12991] & {$[-1.64849]$} \\
\hline & $\Delta M E I P_{t-1}$ & {$[-0.58846]$} & {$[0.11761]$} & {$[2.42997]^{*}$} & {$[-0.06066]$} & {$[-1.80635]$} & {$[-0.68064]$} \\
\hline & $\Delta M E L R_{t-1}$ & {$[-0.25645]$} & {$[-1.47082]$} & {$[2.89073]^{*}$} & {$[-3.05575]^{*}$} & {$[-3.27035]^{*}$} & {$[-2.62724]^{*}$} \\
\hline & $\Delta M E I R_{t-I}$ & {$[-0.05276]$} & {$[-0.57335]$} & {$[2.15518]^{*}$} & {$[-2.24477]^{*}$} & {$[2.82062]^{*}$} & {$[-0.67454]$} \\
\hline & $\Delta M E E R_{t-1}$ & {$[-0.06021]$} & [1.43112] & {$[-1.59683]$} & {$[3.38726]^{*}$} & {$[3.64956]^{*}$} & {$[1.54253]$} \\
\hline & DUM & {$[1.58186]$} & {$[-0.28657]$} & {$[-0.93471]$} & {$[0.03168]$} & {$[-0.30843]$} & {$[-0.35388]$} \\
\hline & & $\triangle R E C A P_{t}$ & $\Delta N S I_{t}$ & $\Delta N I P_{t}$ & $\Delta N L R_{t}$ & $\Delta N I R_{t}$ & $\Delta N E R_{t}$ \\
\hline \multirow{7}{*}{ Nigeria } & $\triangle R E C A P_{t-1}$ & {$[0.49623]$} & {$[-0.92264]$} & [ 0.48755$]$ & {$[-0.79777]$} & {$[5.57162]$} & {$[-0.32796]$} \\
\hline & $\Delta N S I_{t-1}$ & [0.14697] & {$[1.98736]^{*}$} & {$[-0.94523]$} & {$[-1.95098]$} & [1.18624] & {$[-2.66046]^{*}$} \\
\hline & $\Delta N I P_{t-1}$ & [0.10834] & {$[-1.11724]$} & {$[0.19984]^{*}$} & {$[0.10243]$} & {$[0.64146]$} & {$[0.37103]$} \\
\hline & $\Delta N L R_{t-1}$ & {$[0.08261]$} & {$[-1.05777]$} & [0.93014] & {$[0.55353]$} & [0.96073] & [1.08010] \\
\hline & $\Delta N I R_{t-1}$ & {$[0.90727]$} & [0.13893] & {$[0.30941]$} & [0.92853] & {$[0.82327]$} & {$[0.06315]$} \\
\hline & $\Delta N E R_{t-1}$ & {$[-0.33778]$} & [0.57877] & {$[-1.33814]$} & [0.41297] & {$[-0.20402]$} & {$[-1.44853]$} \\
\hline & DUM & {$[-0.55872]$} & {$[-2.05080]^{*}$} & {$[-1.82484]$} & {$[0.88026]$} & {$[-2.81106]^{*}$} & {$[0.22151]$} \\
\hline & & $\triangle R E C A P_{t}$ & $\Delta S S I_{t}$ & $\Delta S I P_{t}$ & $\Delta S L R_{t}$ & $\Delta S I R_{t}$ & $\Delta S E R_{t}$ \\
\hline \multirow{7}{*}{ Spain } & $\triangle R E C A P_{t-1}$ & {$[-0.99012]$} & {$[1.18187]$} & {$[-1.67045]$} & {$[0.05760]$} & {$[-0.22596]$} & {$[-1.56367]$} \\
\hline & $\Delta S S I_{t-1}$ & {$[0.48423]$} & [1.01753] & {$[3.24943]^{*}$} & {$[0.27712]$} & {$[0.02388]$} & {$[0.03662]$} \\
\hline & $\Delta S I P_{t-1}$ & [0.27962] & {$[3.46181]^{*}$} & {$[5.06268]^{*}$} & {$[1.36141]$} & {$[2.67281]^{*}$} & {$[-0.66555]$} \\
\hline & $\Delta S L R_{t-1}$ & {$[0.03075]$} & {$[-1.01815]$} & {$[-0.37167]$} & {$[4.87735]^{*}$} & {$[-0.56391]$} & {$[-0.64453]$} \\
\hline & $\Delta S I R_{t-1}$ & {$[-2.00520]^{*}$} & {$[-3.54643]^{*}$} & {$[-1.88725]$} & {$[-0.22958]$} & [1.83290] & {$[-0.74901]$} \\
\hline & $\Delta S E R_{t-1}$ & {$[-0.45637]$} & {$[-0.32461]$} & {$[0.03801]$} & {$[-0.37685]$} & {$[-1.15285]$} & {$[1.75842]$} \\
\hline & $D U M$ & {$[5.69071]^{*}$} & {$[-1.80032]$} & {$[-1.85565]$} & {$[0.59347]$} & {$[-0.83059]$} & {$[0.27882]$} \\
\hline & & $\triangle R E C A P_{t}$ & $\Delta U S S I_{t}$ & $\Delta U S I P_{t}$ & $\Delta U S L R_{t}$ & $\Delta U_{S I R}$ & $\Delta U S E R_{t}$ \\
\hline \multirow{7}{*}{ USA } & $\triangle R E C A P_{t-1}$ & {$[-0.98666]$} & {$[0.52671]$} & {$[-1.18618]$} & {$[-0.44997]$} & [1.64088] & [1.22094] \\
\hline & $\Delta \boldsymbol{U S S I} \boldsymbol{I}_{t-1}$ & {$[-1.04880]$} & {$[-1.38928]$} & {$[2.91549]^{*}$} & {$[-0.32880]$} & {$[0.36043]$} & {$[-0.05238]$} \\
\hline & $\Delta \boldsymbol{U S I P}_{t-1}$ & {$[-1.20966]$} & {$[2.29551]^{*}$} & {$[8.84390]^{*}$} & {$[0.49751]$} & {$[3.78202]^{*}$} & {$[2.12412]^{*}$} \\
\hline & $\Delta \boldsymbol{U S L R} \boldsymbol{R}_{t-1}$ & {$[-0.97037]$} & [1.03146] & {$[0.49443]$} & {$[0.86099]$} & {$[0.65031]$} & {$[1.22750]$} \\
\hline & $\Delta U S I R_{t-1}$ & {$[-2.52887]^{*}$} & {$[-1.63542]$} & {$[0.04018]$} & {$[-1.07327]$} & [1.25868] & {$[-2.32986]^{*}$} \\
\hline & $\Delta \boldsymbol{U S E R} \boldsymbol{R}_{t-1}$ & {$[1.55760]$} & [1.68435] & [1.24200] & {$[-1.09661]$} & {$[2.28754]^{*}$} & {$[2.56555]^{*}$} \\
\hline & $D U M$ & {$[5.40527]^{*}$} & {$[-1.59552]$} & {$[-1.42053]$} & {$[0.01033]$} & {$[-2.37722]^{*}$} & {$[-1.58850]$} \\
\hline
\end{tabular}

Notes: The asterisk * indicates statistical significance at the 5\% level. See also notes in Table 1 . 
Table 5: ARDL Bounds Test results for the long-run coefficients

\begin{tabular}{|c|c|c|c|c|c|c|}
\hline & \multicolumn{6}{|c|}{ Panel A (Malaysia). Dependent variables } \\
\hline & $R E C A P$ & LMASI & $L M A L R$ & LMAIP & LMAER & $L M A I R$ \\
\hline$E C T$ & $-0.72009 * * *$ & $-0.43378 * * *$ & $-0.35111^{* * *}$ & $-0.12413 * * *$ & $-0.26056^{* * *} *$ & $-0.61168 * * *$ \\
\hline$D U M$ & 0.07392 & $-0.41631 * * *$ & $0.13438 * * *$ & 0.04857 & -0.04196 & $0.25454 *$ \\
\hline RECAP & - & -0.09686 & $-0.30277 * * *$ & 0.51932 & 0.07405 & $-0.50526^{* *}$ \\
\hline LMASI & 0.06201 & - & -0.17494 & $0.88653 * * *$ & $-0.29830 * * *$ & 0.09054 \\
\hline LMALR & -0.22223 & 0.06509 & - & 1.93809 & $0.86024 * * *$ & $0.81519 * *$ \\
\hline LMAIP & $-0.55828 * * *$ & $1.31128 * * *$ & 0.05822 & - & $0.70464 * * *$ & -0.27344 \\
\hline LMAER & 0.22500 & $-2.14279 * * *$ & -0.36815 & 0.76673 & - & -0.42605 \\
\hline LMAIR & $-0.64622 * * *$ & $0.15640 *$ & -0.08494 & $-0.47759 *$ & -0.03990 & - \\
\hline$F$-statistic & $3.60 * *$ & $6.89^{* * *}$ & $6.64 * * *$ & $8.54 * * *$ & $4.22 * * *$ & $6.59 * * *$ \\
\hline$R^{2}$ & 0.4695 & 0.5809 & 0.7353 & 0.7894 & 0.5098 & 0.3569 \\
\hline
\end{tabular}

Panel B (Mexico). Dependent variables

\begin{tabular}{|c|c|c|c|c|c|c|}
\hline & RECAP & LMESI & LMELR & LMEIP & LMEER & LMEIR \\
\hline$E C T$ & $-0.47378 * * *$ & $-0.55648 * * *$ & $-0.07118 * * *$ & $-0.35430 * * *$ & $-0.56131 * * *$ & $-0.24635^{* * *} *$ \\
\hline$D U M$ & $0.55361 * * *$ & -0.03021 & -1.16690 & 0.13941 & 0.09694 & $0.62175 * * *$ \\
\hline$R E C A P$ & - & 0.33601 & -5.28122 & -0.09514 & 0.01546 & $-0.94469 * *$ \\
\hline LMESI & $0.18265 * * *$ & - & 8.45702 & $0.14648 * * *$ & 0.10722 & 0.08779 \\
\hline LMELR & $0.16766^{* *}$ & 0.19305 & - & $-0.12060 * *$ & -0.08270 & $0.73827 * * *$ \\
\hline LMEIP & $-0.93466^{*}$ & $4.57880 * * *$ & -36.91101 & - & $-1.24941 * * *$ & -1.38635 \\
\hline LMEER & -0.06420 & $2.87776^{* * * *}$ & -0.04235 & $-1.01097 * *$ & - & 0.93500 \\
\hline LMEIR & $-0.17648 * * *$ & $-0.99084 * * *$ & 6.99697 & $0.20628^{* *}$ & 0.03825 & - \\
\hline$F$-statistic & $11.06^{* * *}$ & $6.04 * * *$ & $3.52 * *$ & $6.55^{* * *}$ & $3.94 * *$ & $3.44 * *$ \\
\hline$R^{2}$ & 0.5568 & 0.7266 & 0.9481 & 0.9746 & 0.8992 & 0.8521 \\
\hline
\end{tabular}

Panel C (Nigeria). Dependent variables

\begin{tabular}{|c|c|c|c|c|c|c|}
\hline & $R E C A P$ & LNSI & LNLR & $L N I P$ & LNER & LNIR \\
\hline$E C T$ & $-0.86318 * * *$ & -0.46714 *** & $-0.08400^{* * *}$ & $-0.09668 * *$ & $-1.56345^{*} * *$ & $-0.49605 * * *$ \\
\hline$D U M$ & $-0.18090 * *$ & -0.26980 & 0.08960 & -0.96179 & -0.04770 & $1.02009 * *$ \\
\hline RECAP & - & -1.83961 & 0.22922 & $-3.26329 *$ & 0.10635 & -1.33342 \\
\hline LNSI & $-0.24089^{*}$ & - & -0.57952 & -0.53893 & 0.17347 *** & $-1.90534 * *$ \\
\hline LNLR & $-1.64605 * * *$ & -1.94164 & - & $-8.70401 *$ & $1.26418^{* *}$ & $-9.90326 * *$ \\
\hline$L N I P$ & $-0.17827 * * *$ & $-0.39771 * *$ & 0.06466 & - & $0.09232 * * *$ & $-0.65685^{* *}$ \\
\hline LNER & $1.32138 * * *$ & $4.32697 * * *$ & -0.17003 & 7.07325 *** & - & $8.88496^{* * *}$ \\
\hline LNIR & 0.06640 & 0.19883 & -0.43656 & 0.38878 & -0.01008 & - \\
\hline$F$-statistic & $5.01 * * *$ & $5.78 * * *$ & $3.71 * *$ & 1.02 & $16.48 * * *$ & $5.86^{* * *}$ \\
\hline$R^{2}$ & 0.8432 & 0.9497 & 0.8054 & 0.1023 & 0.9979 & 0.8756 \\
\hline
\end{tabular}

Panel D (Spain). Dependent variables

\begin{tabular}{|c|c|c|c|c|c|c|}
\hline & RECAP & LSSI & $L S L R$ & LSIP & LSER & LSIR \\
\hline$E C T$ & $-0.61939 * * *$ & -0.35311 *** & $-0.00204 * * *$ & $-0.03901 * * *$ & $-0.42090 * * * *$ & $-0.30771 * * *$ \\
\hline$D U M$ & $0.63603 * * *$ & $0.39383 * * *$ & -54.75840 & -0.21825 & -0.02379 & 0.99164 \\
\hline$R E C A P$ & - & $0.85891 * *$ & 56.56494 & 0.55280 & -0.03508 & -1.07974 \\
\hline LSSI & -0.19535 & - & 57.83870 & -0.44750 & $0.35526^{*}$ & $-2.27934 * *$ \\
\hline LSLR & $0.20098 *$ & $-0.46904 * * *$ & - & -0.39170 & -0.03804 & -0.09079 \\
\hline LSIP & $0.64607 *$ & -0.05184 & -78.10339 & - & 0.37778 & $16.90725 * * *$ \\
\hline LSER & 0.05140 & $2.20238 * * *$ & -79.49320 & $1.57139 *$ & - & $-4.15765^{* *}$ \\
\hline LSIR & $-0.21539 * * *$ & $-0.27221 * * *$ & 29.34184 & 0.03156 & $0.30119 * *$ & - \\
\hline$F$-statistic & $11.29 * * *$ & $6.86^{* * *}$ & $4.49 * * *$ & $4.90 * * *$ & $5.11 * * *$ & $4.86^{* * *}$ \\
\hline$R^{2}$ & 0.8422 & 0.8331 & 0.7563 & 0.8461 & 0.9296 & 0.6067 \\
\hline
\end{tabular}

Panel E (USA). Dependent variables

\begin{tabular}{|c|c|c|c|c|c|c|}
\hline & $R E C A P$ & LUSSI & LUSLR & LUSIP & LUSER & LUSIR \\
\hline$E C T$ & $-0.34850 * * *$ & $-0.16495 * * *$ & $-0.01378 * * *$ & $-0.13154 * * *$ & $-0.19276 * * *$ & $-0.99586 * * *$ \\
\hline$D U M$ & $0.43350 * * *$ & 0.26045 & 3.57630 & 0.06347 & $0.21537 * *$ & $-0.38536^{* *}$ \\
\hline RECAP & - & $-0.54782 *$ & -10.52071 & $-0.18666^{*}$ & $-0.59783 * * *$ & $0.67940 * *$ \\
\hline LUSSI & -0.14406 & - & -1.13706 & $0.15772 * *$ & $-0.91326 * * *$ & $-1.05721 * *$ \\
\hline LUSLR & $-0.95489 * * *$ & -1.11896 & - & -0.27647 & $-0.66017 *$ & 2.18331 **** \\
\hline LUSIP & -0.09880 & $2.06543 * *$ & -5.15915 & - & $2.70746 * * *$ & $3.95517 * *$ \\
\hline LUSER & $0.52674^{*}$ & -0.83157 & -3.24697 & $0.48110 * *$ & - & $1.62894 * * *$ \\
\hline LUSIR & $0.10164 *$ & 0.02433 & -0.40343 & 0.02734 & 0.03696 & - \\
\hline$F$-statistic & $9.02 * * *$ & $3.39 * *$ & $5.59 * * *$ & $5.29 * * *$ & $5.28 * * *$ & $4.27 * * *$ \\
\hline$R^{2}$ & 0.6122 & 0.2285 & 0.7852 & 0.9482 & 0.7025 & 0.5055 \\
\hline
\end{tabular}

Notes: The asterisk *** (**) $(*)$ indicates statistical significance at the $1 \%, 5 \%$ and $10 \%$ levels, respectively. ECT is the error correction term which is obtained from the cointegrating form that also shows the short-term parameters. The other parameters in this table are for the long-term effects. In all cases, ECT is significant and negative as required. F-statistic is for the Bounds test; the absence of any asterisk means that there is either no cointegration or we do not have conclusive evidence, otherwise we reject the null hypothesis that there is no long-run relationship. The critical I( $(0)[\mathrm{I}(1)]$ values for the Bounds test are 2.08 [3.00], 2.39 [3.38] and 3.06 [4.15] for the significance level of $10 \%, 5 \%$ and 1\%, respectively. See also notes in Table 1. 
Table 6: Generalised Forecast Error Variance Decomposition Results

\begin{tabular}{|c|c|c|c|c|c|c|c|c|c|c|c|c|c|c|}
\hline Period & \multicolumn{7}{|c|}{ Panel A: Malaysia } & \multicolumn{7}{|c|}{ Panel B: Mexico } \\
\hline 1 & 0.1449 & 100.00 & 0.00 & 0.00 & 0.00 & 0.00 & 0.00 & 0.1530 & 100.00 & 0.00 & 0.00 & 0.00 & 0.00 & 0.00 \\
\hline 3 & 0.2517 & 99.27 & 0.01 & 0.53 & 0.05 & 0.13 & 0.00 & 0.2595 & 97.93 & 1.73 & 0.25 & 0.05 & 0.02 & 0.01 \\
\hline 4 & 0.2905 & 99.12 & 0.01 & 0.56 & 0.06 & 0.24 & 0.01 & 0.2992 & 97.29 & 2.25 & 0.36 & 0.04 & 0.05 & 0.01 \\
\hline 5 & 0.3247 & 99.01 & 0.02 & 0.57 & 0.07 & 0.32 & 0.01 & 0.3343 & 96.87 & 2.59 & 0.41 & 0.03 & 0.08 & 0.01 \\
\hline \multirow[t]{2}{*}{8} & 0.4105 & 98.87 & 0.02 & 0.59 & 0.09 & 0.43 & 0.01 & 0.4222 & 96.32 & 3.06 & 0.46 & 0.02 & 0.12 & 0.02 \\
\hline & \multicolumn{7}{|c|}{ Panel C: Nigeria } & \multicolumn{7}{|c|}{ Panel D: Spain } \\
\hline Period & S.E. & RECAP & $N S I$ & NIP & $N L R$ & NIR & $N E R$ & S.E. & RECAP & $S S I$ & SIP & SLR & SIR & SER \\
\hline 1 & 0.1657 & 100.00 & 0.00 & 0.00 & 0.00 & 0.00 & 0.00 & 0.1200 & 100.00 & 0.00 & 0.00 & 0.00 & 0.00 & 0.00 \\
\hline 2 & 0.2314 & 99.77 & 0.03 & 0.07 & 0.04 & 0.07 & 0.02 & 0.1466 & 96.78 & 2.14 & 0.02 & 0.02 & 1.00 & 0.04 \\
\hline 3 & 0.2772 & 99.39 & 0.04 & 0.28 & 0.23 & 0.05 & 0.02 & 0.1722 & 87.33 & 4.90 & 0.72 & 0.15 & 6.85 & 0.05 \\
\hline \multirow[t]{2}{*}{8} & 0.3997 & 95.83 & 0.04 & 1.61 & 1.85 & 0.49 & 0.18 & 0.3205 & 42.21 & 18.20 & 11.02 & 2.13 & 26.21 & 0.22 \\
\hline & \multicolumn{7}{|c|}{ Panel E: USA } & & & & & & & \\
\hline Period & S.E. & RECAP & USSI & USIP & USLR & USIR & USER & & & & & & & \\
\hline 1 & 0.1147 & 100.00 & 0.00 & 0.00 & 0.00 & 0.00 & 0.00 & & & & & & & \\
\hline 2 & 0.1434 & 95.96 & 0.39 & 0.29 & 1.89 & 0.22 & 1.25 & & & & & & & \\
\hline 3 & 0.1686 & 89.28 & 0.39 & 0.61 & 3.52 & 4.62 & 1.58 & & & & & & & \\
\hline 4 & 0.1944 & 81.64 & 0.30 & 0.48 & 4.49 & 11.02 & 2.07 & & & & & & & \\
\hline 5 & 0.2198 & 74.98 & 0.30 & 0.53 & 4.89 & 16.53 & 2.77 & & & & & & & \\
\hline 6 & 0.2441 & 69.56 & 0.53 & 1.09 & 4.94 & 20.34 & 3.55 & & & & & & & \\
\hline 7 & 0.2673 & 65.18 & 0.95 & 2.12 & 4.80 & 22.65 & 4.30 & & & & & & & \\
\hline 8 & 0.2894 & 61.66 & 1.48 & 3.40 & 4.58 & 23.90 & 4.97 & & & & & & & \\
\hline
\end{tabular}


Table 7: Toda Yamamoto (T-Y) procedure for Granger causality

\begin{tabular}{lcccccc}
\hline & \multicolumn{7}{c}{ Panel A (Malaysia). Dependent variables } \\
\hline RECAP & LECAP & LMASI & LMALR & LMAIP & LMAER & LMAIR \\
LMASI & - & 4.13236 & 6.61176 & 7.14548 & 1.60917 & $10.85870^{*}$ \\
LMALR & 3.37907 & - & 2.07536 & $21.1076^{* * *}$ & 1.33033 & 1.86495 \\
LMAIP & 1.35612 & $27.1675^{* * *}$ & - & 6.33590 & 7.63983 & 6.26956 \\
LMAER & 0.48710 & $22.4280^{* * *}$ & $17.8671^{* * *}$ & 7.88175 & 4.98145 & 5.32511 \\
LMAIR & 4.65323 & 7.17492 & $9.27062^{*}$ & 5.22405 & - & 1.19573 \\
& & & & & $-99498^{*}$ & -
\end{tabular}

Panel B (Mexico). Dependent variables

\begin{tabular}{lcccccc}
\hline & $\boldsymbol{R E C A P}$ & LMESI & LMELR & LMEIP & LMEER & LMEIR \\
\hline RECAP & - & $10.8832^{*}$ & 3.80385 & 9.78369 & $11.1126^{*}$ & 6.86133 \\
LMESI & 6.91732 & - & $12.2838^{* *}$ & 9.14194 & $11.3247^{*}$ & 9.23310 \\
LMELR & 5.47333 & 5.50462 & - & $14.9321^{* *}$ & $14.6757^{* *}$ & 7.90842 \\
LMEIP & 8.05011 & $17.9365^{* * *}$ & 3.80203 & - & 2.24399 & 7.49692 \\
LMEER & 5.39719 & 5.94155 & 8.45266 & 3.84747 & - & $20.6929 * * *$ \\
LMEIR & 2.31881 & 9.50225 & 4.35414 & 3.20243 & 2.55983 & -
\end{tabular}

Panel C (Nigeria). Dependent variables

\begin{tabular}{|c|c|c|c|c|c|c|}
\hline & $R E C A P$ & LNSI & $L N L R$ & LNIP & LNER & LNIR \\
\hline RECAP & - & 3.16058 & 0.86010 & 2.14256 & 0.56960 & 1.82657 \\
\hline LNSI & $4.65649 *$ & - & 2.16113 & $4.09492 *$ & $7.94846^{* *}$ & 2.94388 \\
\hline LNLR & 1.64502 & 2.67084 & - & 2.03233 & 2.01471 & 1.16932 \\
\hline LNIP & 0.23746 & 0.76062 & $5.39239 *$ & - & 0.15429 & 2.12860 \\
\hline LNER & 0.50028 & 1.71664 & 3.91797 & 0.65906 & - & 2.53498 \\
\hline LNIR & 3.39738 & 1.01681 & 0.62764 & 0.34743 & 0.53665 & - \\
\hline
\end{tabular}

\begin{tabular}{lcccccc}
\hline \multicolumn{7}{c}{ Panel D (Spain). Dependent variables } \\
\hline $\boldsymbol{R E C A P}$ & $\boldsymbol{R E C A P}$ & $\boldsymbol{L S S I}$ & $\boldsymbol{L S L R}$ & $\boldsymbol{L S I P}$ & $\boldsymbol{L S E R}$ & $\boldsymbol{L S I R}$ \\
$\boldsymbol{L S S I}$ & - & 3.80201 & 4.22609 & $21.8679^{* * *}$ & $13.3547^{*}$ & $26.2223^{* * *}$ \\
$\boldsymbol{L S L R}$ & 10.4463 & - & $13.8791^{*}$ & 8.08399 & 1.92731 & $17.6108^{* *}$ \\
$\boldsymbol{L S I P}$ & $39.1149 * * *$ & $13.6971^{*}$ & - & 4.32967 & 8.77125 & 5.56774 \\
$\boldsymbol{L S E R}$ & $31.0438^{* * *}$ & 3.56028 & 7.98673 & - & 5.89869 & $13.4670^{*}$ \\
$\boldsymbol{L S I R}$ & $20.3932^{* * *}$ & 5.15461 & 8.32314 & 7.75401 & - & 6.66378 \\
& $13.7133^{*}$ & 9.14140 & 7.67445 & 3.54163 & $13.0361^{*}$ & -
\end{tabular}

\begin{tabular}{lcccccc}
\hline \multicolumn{5}{c}{ Panel E $(\boldsymbol{U S A})$. Dependent variables } \\
\hline $\boldsymbol{R E C A P}$ & $\boldsymbol{R E C A P}$ & LUSSI & LUSLR & LUSIP & LUSER & LUSIR \\
LUSSI & - & $19.1293^{* *}$ & $14.6112^{*}$ & $31.5527^{* * *}$ & $28.8800^{* * *}$ & 8.76400 \\
$\boldsymbol{L} \boldsymbol{U S \boldsymbol { R }}$ & $13.2686^{*}$ & - & 4.91812 & $14.1926^{*}$ & $20.0668^{* *}$ & 9.50365 \\
$\boldsymbol{L} \boldsymbol{U S I P}$ & 15.11412 & 6.59257 & - & $18.6797^{* *}$ & $15.9755^{*}$ & 7.35828 \\
$\boldsymbol{L} \boldsymbol{U S E R}$ & 10.3744 & 11.2742 & 10.7370 & - & $43.9053^{* * *}$ & $14.6394^{*}$ \\
$\boldsymbol{L} \boldsymbol{U S I R}$ & 9.62552 & 12.1613 & 10.2330 & 10.5717 & - & 10.9003 \\
\hline
\end{tabular}

Notes: The asterisk $* * *(* *)(*)$ indicates statistical significance (i.e., presence of causality) at the $1 \%, 5 \%$ and $10 \%$ levels, respectively. We report the M-Wald statistic that has $\chi 2$ distribution. See also notes in Table 1. 
Figure 1: Accumulated Responses of Malaysia Macroeconomic Variables to Innovations due to Recapitalization

Accumulated Response of RECAP to Generalized One D. RECAP Innovation

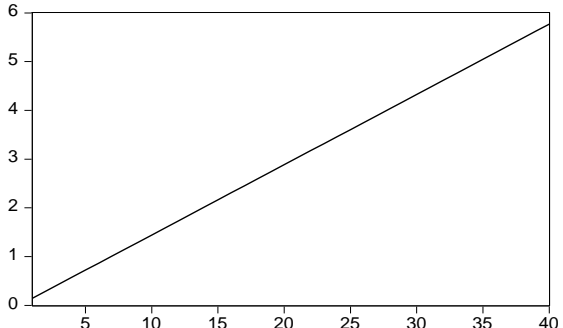

Accumulated Response of MAIP to Generalized One S.D. RECAP Innovation

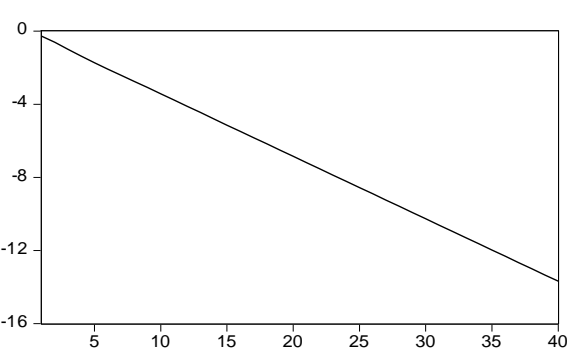

Accumulated Response of MAIR to Generalized One S.D. RECAP Innovation

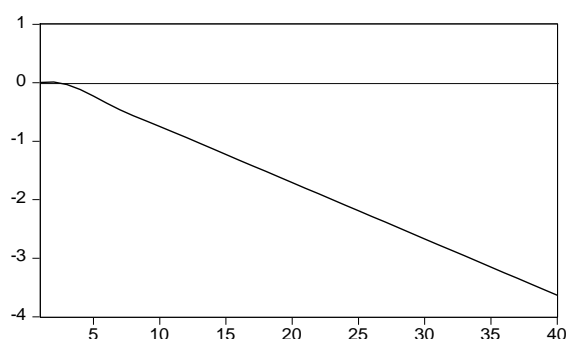

Accumulated Response of MASI to Generalized One

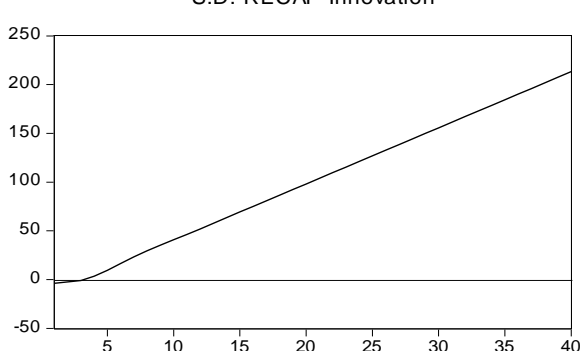

Accumulated Response of MALR to Generalized One

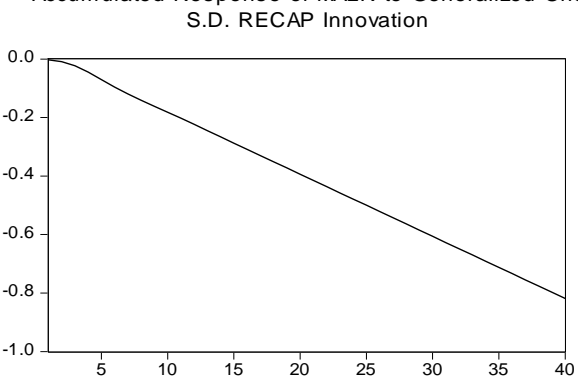

Accumulated Response of MAER to Generalized One S.D. RECAP Innovation

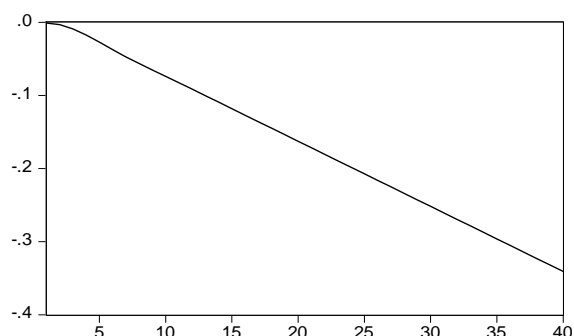

Figure 2: Accumulated Responses of Mexico Macroeconomic Variables to Innovations due to Recapitalization

Accumulated Response of RECAP to Generalized On

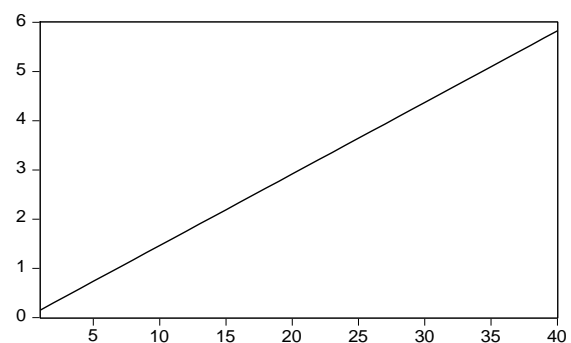

Accumulated Response of MEIP to Generalized One D. RECAP Innovation

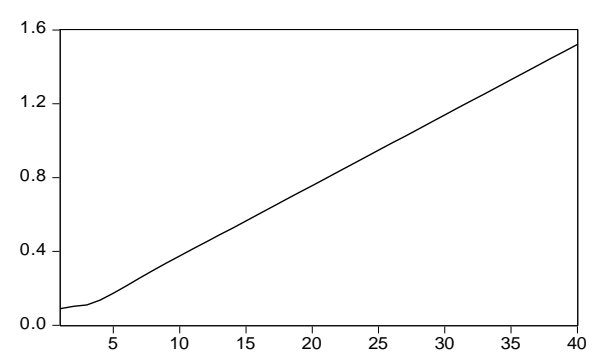

Accumulated Response of MEIR to Generalized One S.D. RECAP Innovation

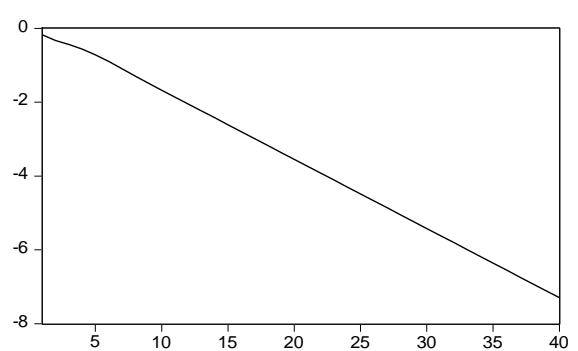

Accumulated Response of MESI to Generalized On RECAP Innovation

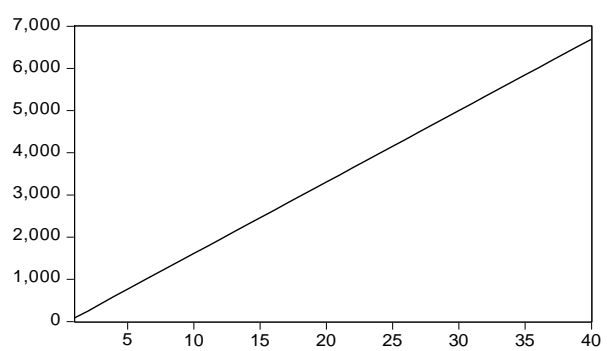

Accumulated Response of MELR to Generalized On S.D. RECAP Innovation

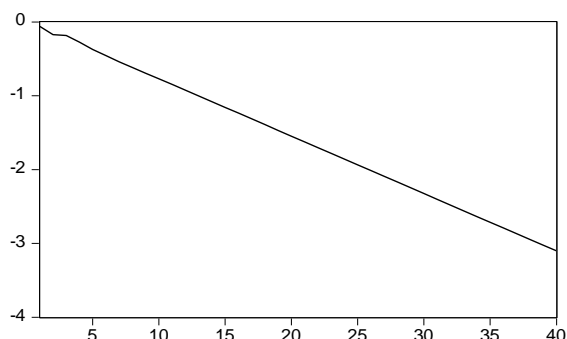

Accumulated Response of MEER to Generalized On S.D. RECAP Innovation

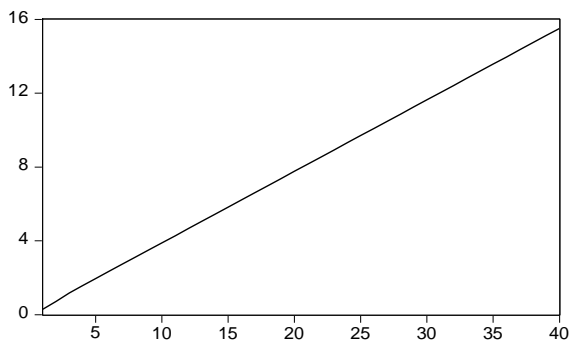


Figure 3: Accumulated Responses of Nigeria Macroeconomic Variables to Innovations due to Recapitalization

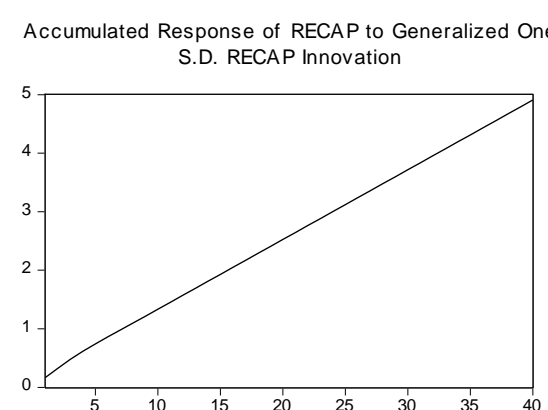

Accumulated Response of NSI to Generalized One

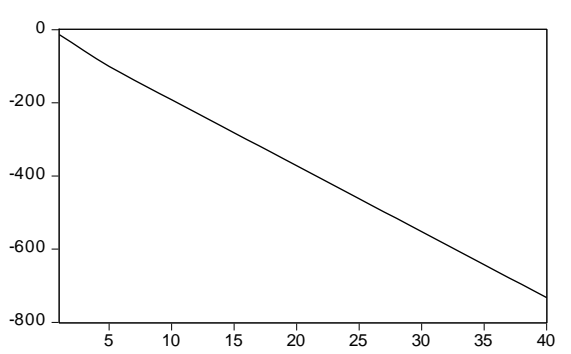

Accumulated Response of NIP to Generalized On S.D. RECAP Innovation

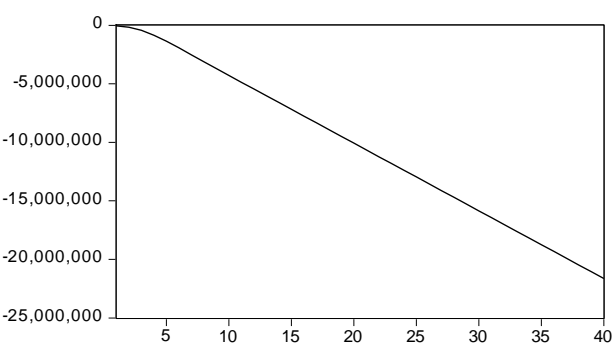

Accumulated Response of NIR to Generalized One S.D. RECAP Innovation

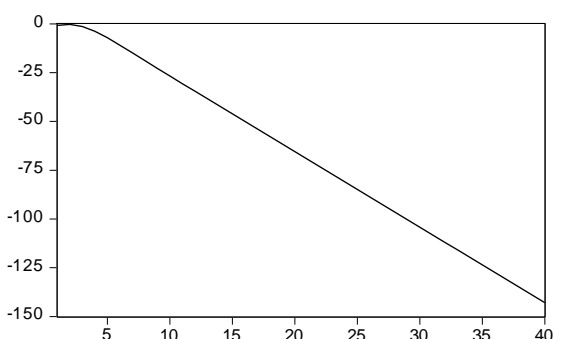

Accumulated Response of NLR to Generalized One

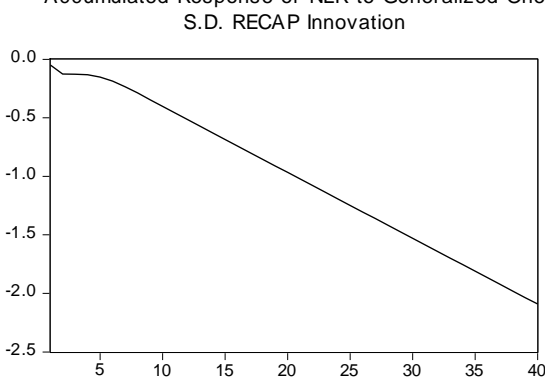

Accumulated Response of NER to Generalized On

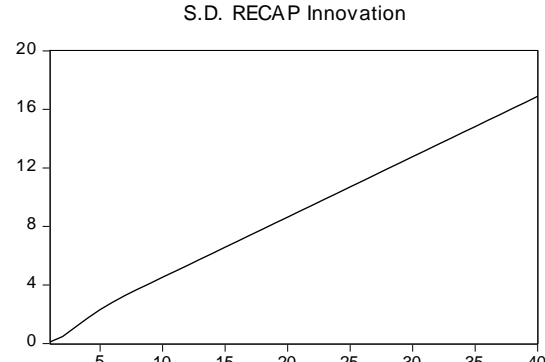

Figure 4: Accumulated Responses of Spain Macroeconomic Variables to Innovations due to Recapitalization

Accumulated Response of RECAP to Generalized One

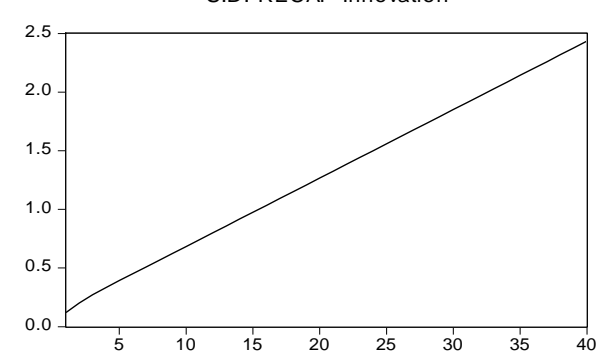

Accumulated Response of SIP to Generalized One S.D. RECAP Innovation

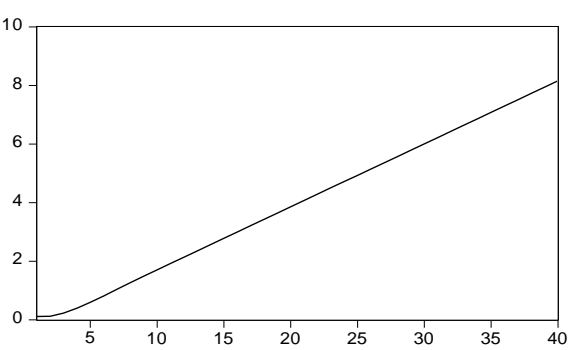

Accumulated Response of SIR to Generalized One

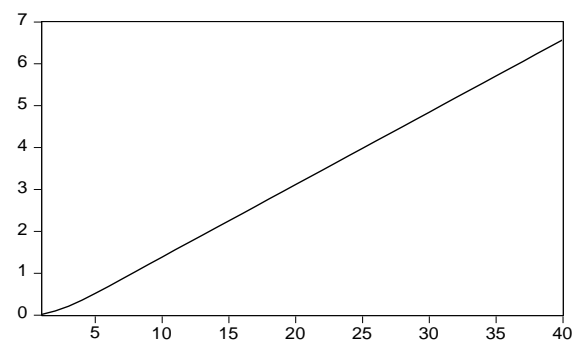

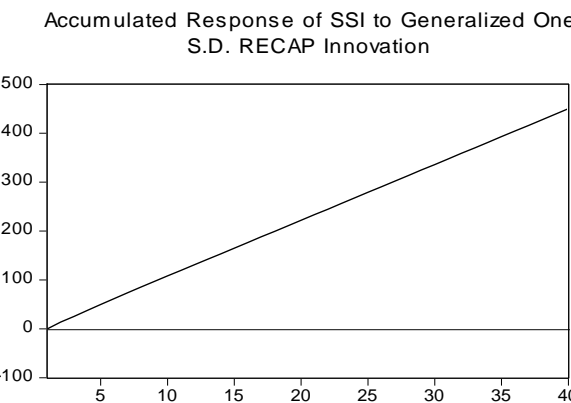

Accumulated Response of SLR to Generalized On S.D. RECAP Innovation

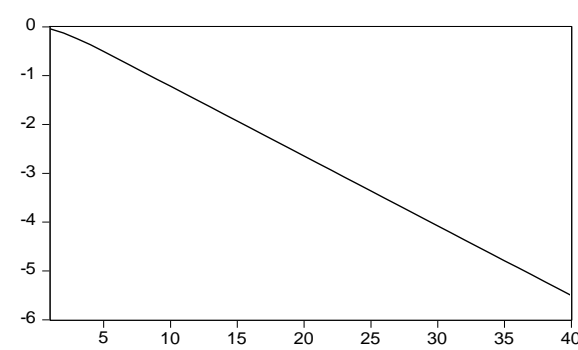

Accumulated Response of SER to Generalized One S.D. RECAP Innovation

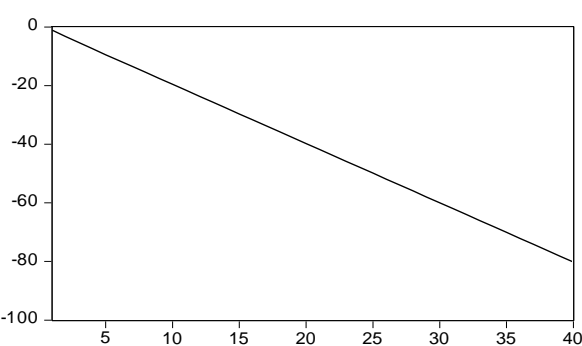


Figure 5: Accumulated Responses of USA Macroeconomic Variables to Innovations due to Recapitalization

Accumulated Response to Generalized One S.D. Innovations

Accumulated Response of RECAP to RECAP

Accumulated Response of USSI to RECAP
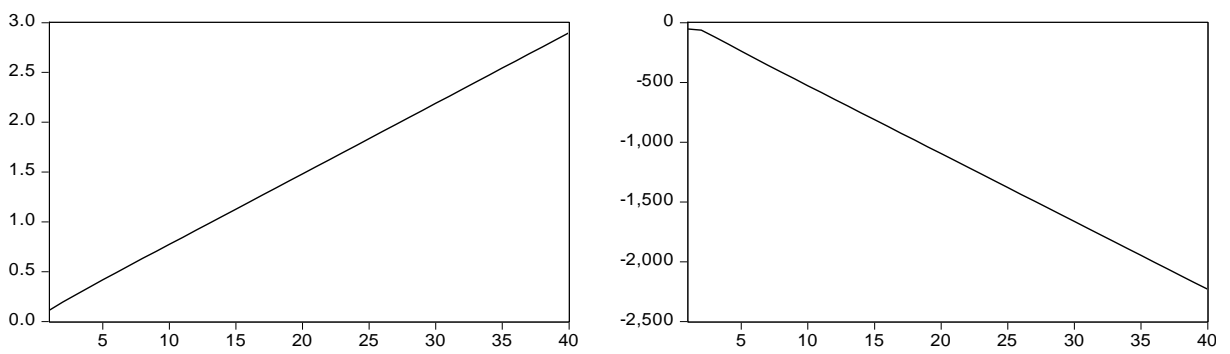

Accumulated Response of USIP to RECAP
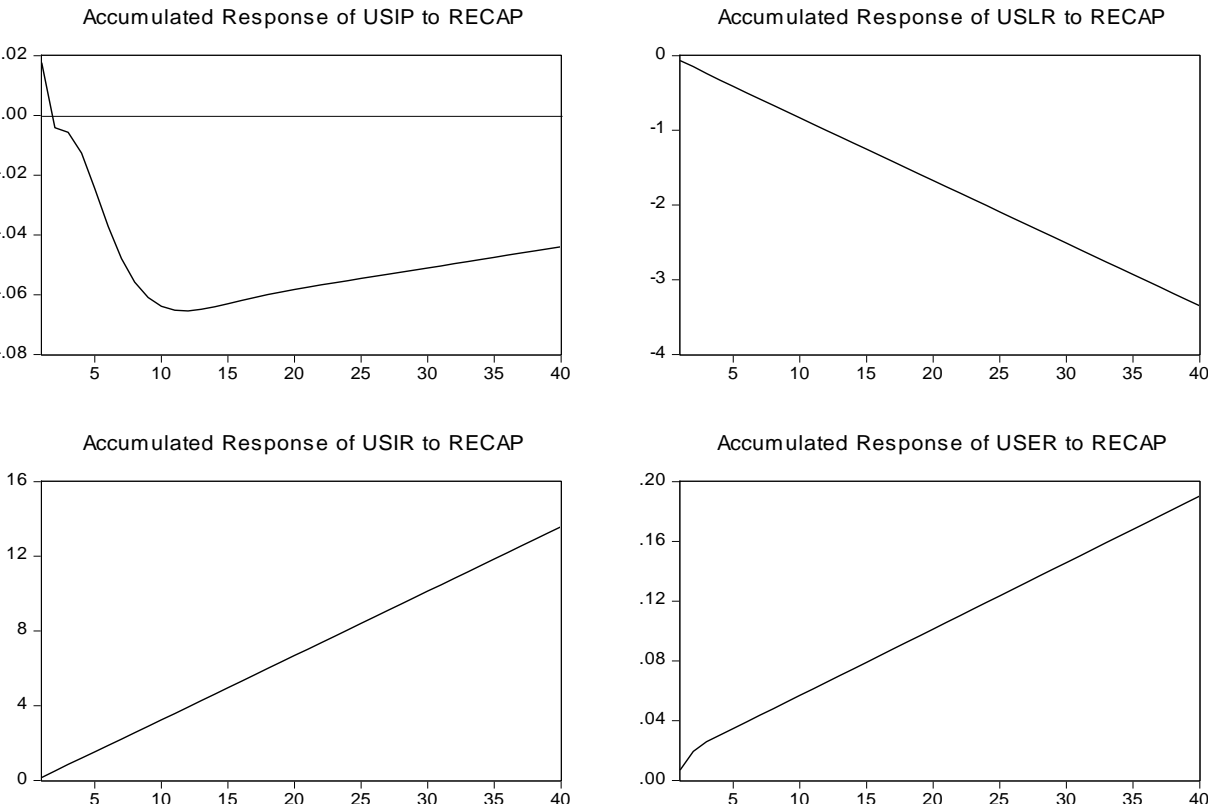